\title{
ENTRE LA CARNE Y EL ESPÍRITU. EL CLERO SOLICITANTE VALENCIANO (SIGLOS XVIII-XIX)
}

\author{
Vicente LEÓN NAVARRo \\ (IES «F. Ferrer i Guàrdia»)
}

Aceptado: 1-V-2005.

RESUMEN: La Iglesia ha defendido el celibato clerical como el estado perfecto para sus ministros. Era una forma también de control. Pero este clero célibe no ha sido inmune a los encantos de la carne representados en la mujer, en menar cantidad también en el hombre, sucumbiendo a ellos. Para evitar que la confesión se convirtiera en una ocasión de oro para estas situaciones Clemente VIII puso bajo la jurisdicción del Santo Oficio a los confesores que solicitaran a los penitentes. Gracias a eso contamos una documentación preciosa. Palabras Clave: Santo Oficio, Solicitación, Clero, Celibato, Confesión.

ABSTRACT: The Church has defended clerical celibacy as the perfect state for its ministers. It was also a form of control. But this celibate clergy has not been immune to the charms of the flesh represented mainly by women, but aiso to a lesser extent by men, and succumb to them. To avoid the confession turning into a golden opportunity for these situations, the Pope Clement VIII, put under the jurisdiction of the Holy Office the confessors that took advantage of the penitents. Thanks to this we have a beautiful documentation. Key Words: Holy Office, Soliciting, Clergy, Celibacy, Confession.

\section{La confesión auricular.}

La confesión auricular, acto heroico según Luis de la Puente, como autodenuncia ha dado pie a muchas controversias y creado suspicacias entre la Iglesia docente y discente, entre clérigos y fieles, desde que el Concilio de Letrán IV (1215) impusiera su obligación anual en el mundo cristiano, modificando la vida religiosa ${ }^{1}$ de los hombres y mujeres sometidos al poder eclesiástico. El Concilio de Trento mantuvo y afianzó este

\footnotetext{
'Jean Delumeau, La confesión y el perdón. Las dificultades de la confesión, siglos XIII a XVIII, Alianza Editorial, Madrid, 1992, pp. 15-16. Versión española de Mauro Armiño.
} 
sistema sacramental esencial a la Iglesia y a sus ministros; a través de él controlaban a los penitentes erigiéndose en árbitros de su salvación o condenación. El confesor venía a ser un pequeño dios humano, ${ }^{2}$ a veces miserable, conocedor de las intimidades, vicios y flaquezas de cada hombre. La Iglesia ha aprovechado ese poder pregonando y explotando profusamente la teología del pecado, cultura del pecado la llama Delumeau, ${ }^{3}$ en la que el hombre, esencialmente pecador y culpable de serlo, ignorante, minusválido, siempre menor de edad y temeroso del misterio, queda reducido a la nada, al agujero negro de la propia desesperación y muerte espiritual. La solución pasaba por la confesión indispensable y por el confesor convertido en el administrador del perdón y de la penitencia expiatoria. De esta forma el proceso devenía en una adicción permanente, en un círculo invariable, habitual y estéril de pecado-confesión-perdón-pecado..., que vemos en fray Valentín de la Madre de Dios, ${ }^{4}$ porque el sacramento de la penitencia no es el de la conversión, sino el de la rutina, en el que resulta difícil distinguir entre atrición, contrición o proceso mecánico sin conciencia de pecado, que responde a una imposición. ${ }^{5}$ Y como a tal hay que considerarla. Confesión y comunión anual que los obispos vigilarán a través de los párrocos. ${ }^{6}$

Los confesores abusaron de su poder y no fueron pocos los fieles que buscaron la forma de eludir esta obligación como pudieron, unos realizando confesiones falsas, otros contando con la ayuda del confesor que concedía cédulas a cambio de favores, ${ }^{7}$ y muchos lamentando la cercanía de la Cuaresma. ${ }^{8}$ Era evidente la tiranía espiritual del poder eclesiástico al que aluden el barón d'Holbach en su Moral Universal y Volney en Las ruinas de Palmira. Quienes creyeron y siguieron el maniqueísmo eclesiástico sufrieron verdaderos traumas (miedo, ansiedad, angustia...) reflejados en documentos y autores conscientes de la degradación del confesionario que el obispo Bertrán quería

\footnotetext{
${ }^{2}$ Vicente León Navarro, *Violencia clerical-anticlerical. Realidad y percepción episcopal a través de las visitas ad liminam, Anales Valentinos, $\mathrm{n}^{\circ} 60$ (2005), pp. 305-353.

${ }^{3}$ Jean Delumeau, La pêche et la peur. La culpabilisation en Occident XIII-XVIIe siècles, Fayard, Paris, 1983.

${ }^{4}$ Fray Valentín de la Madre de Dios, El fuero de la conciencia o diálogo entre un confesor y un penitente a propósito del sexto mandamiento. Estudio preliminar de Gérard Dufour, Alicante, 1994. Vicente León Navarro, Luis de Granada y la tradición erasmista en Valencia. Siglo XVIII. Alicante, 1986. Importa la Pastoral sobre la penitencia de Felipe Bertrán.

${ }_{5}^{5}$ Gérard Dufour, Clero y sexto mandamiento. La confesión en la España del siglo XVIII, Ámbito, Valladolid, 1996, p. 56. Los jesuitas de puertas adentro o Un barrido hacia fuera en la Compañía de Jesús, Tipolitografía de Luis Tasso, Barcelona, p. 263.

${ }^{6}$ Vicente León Nayarro, «Benimaclet en sus visitas pastorales. Siglos XVII-XIX. Algunas notas para su estudio", Anales Valentinos, $\mathbf{n}^{\circ} 43$ (1996), pp. 169-205. Edicto del arzobispo de Valencia Fabián y Fuero de 1776 recogiendo los de su antecesor, Andrés Mayoral, de 1741 y 1759 sobre este tema, Biblioteca Universidad de Valencia, Ms. 860/20.

${ }^{7}$ Caso del mercedario Agustín Cabadés. Archivo Histórico Nacional (AHN), Inquisición, legajo 562/6.

8 Antonio Viñao Frago, «Libertinos y republicanos en la Murcia del cambio de siglo. Manuel José Narganes y José Ibarrola: el Seminario de San Fulgencio y la Real Fábrica de la seda», en La Revolución Francesa, su influencia en la educación en España, UNED, Madrid, 1990, pp. 392 y ss.
} 
ver a salvo gracias al Santo Oficio. ${ }^{9}$ Se equivocaba el buen obispo e Inquisidor General a pesar del empeño del Tribunal para mantener viva la idea sacramental elegida por el Concilio de Trento frente a los reformadores más inclinados a la palabra. En esta línea el fiscal acusaba al solicitante agustino Jerónimo Almiñana (1705):

\begin{abstract}
de que deviendo administrar el santo sacramento de la Penitencia con la devida pureza y reverencia, excitando a sus penitentes al verdadero arrepentimiento de sus culpas y guiarlas por el camino de la perfección, olvidando de tan grandes obligaciones y pospuesto el temor de Dios Nuestro Señor en grave daño de su conciencia y en menosprecio de la justicia santa que en este tribunal se administra, havía solicitado a diferentes mujeres en el acto de confesión.... ${ }^{10}$
\end{abstract}

No es extraño que ante este panorama moral poco halagüeño se adoptaran medidas regeneradoras encaminadas, primero, a formar adecuadamente al clero en seminarios, ${ }^{11}$ al calor de las reformas del siglo XVI y de las ideas pedagógicas del XVIII, seleccionarlo luego para la vida pastoral a través de oposiciones, licencias de confesar y predicar, reciclarlo a través de las Conferencias morales y someterlo a revisiones periódicas según cada prelado. La necesidad de reformar la Iglesia fue asumida por casi todos los sectores sociales mirando el ejemplo de los primeros siglos. No obstante tan buenas intenciones, los resultados no fueron siempre satisfactorios, dados los intereses contrapuestos y la situación de muchos obispados. Los prelados, entre los que contamos con ejemplos muy loables, no utilizaron de forma adecuada su poder, enfrascados a veces en otros menesteres menos dignos, ${ }^{12}$ mirando con laxitud las transgresiones morales de su clero ${ }^{13}$ mientras perseguían con singular saña las disidencias ideológicas o las críticas

\footnotetext{
${ }^{9}$ Joaquín Lorenzo Villanueva, Vida Literaria. Edición, introducción y notas de Germán Ramírez Aledón, Alicante, 1996, p. 135 , nota 30.

${ }^{10}$ Archivo Universidad de Valencia (AUV), Varios, caja $48 / 5$

${ }^{11}$ Francisco Martín Hernández, Los seminarios españoles en la época de la llustración, CSIC, Madrid, 1973; Id., "La formación del clero en los siglos XVII y XVII", Historia de la Iglesia en España IV. La Iglesia en la España de los siglos XVI y XVIII, dirigida por Ricardo García Villoslada, BAC, Madrid, 1979. Cayetano Mas Galvañ, Jansenismo y reforma educativa en la España ilustrada: El Seminario de San Fulgencio de Murcia, Tesis de doctorado, Alicante, 1986. Del mismo autor otros trabajos de gran interés que ahondan en esta misma línea. Antonio Mestre Sanchis, «Religión y Cultura en el siglo XVIII español», Historia de la Iglesia en España IV... Vicente León Navarro, Luis de Granada... María Luisa Candau, La carrera eclesiástica en el siglo XVIII, Universidad de Sevilla, 1993.

12 Vicente León Navarro, "Cara y cruz del clero valenciano. Las visitas ad limina (1750-1868)», Trienio. Ilustración y Liberalismo, $\mathbf{n}^{\circ} 22$ (1993), pp. 5-35. La crítica a los obispos por parte de Mayans en Antonio Mestre Sanchis, Ilustración y Reforma de la Iglesia. Pensamiento político-religioso de don Gregorio Mayans y Siscar (1699-1781), Valencia, 1966. Gregorio Mayans y Siscar, Epistolario XVIII. Correspondencia de los hermanos Mayans con el canónigo Juan Bautista Hermán I, estudio preliminar, transcripción y notas por Vicente León Navarro con la colaboración de Erena León La Parra, Publicaciones del Ayuntamiento de Oliva, Valencia, 2001. Id., Epistolario XIX..., 2002.

${ }^{13}$ Gérard Dufour, Clero y sexto..., pp. 37 y ss. No obstante, el arzobispo Fabián y Fuero alababa a su clero tanto por su formación como por su trabajo, aunque condenaba con cierta visceralidad al clero regular. Vicente León Navarro, «Cara y Cruz...», p. 15.
} 
a sus gestiones..$^{14} \mathrm{La}$ jerarquía no necesitaba opositores críticos, sino fieles servidores aunque moralmente fuesen poco recomendables, si bien menudearon las denuncias contra ese clero malo y vicioso (mercenario, borracho, avaricioso, incontinente, etcétera). Torres Villarroel lo ridiculiza en sus obras por no responder al ideal ilustrado.

Parece demostrado que la formación del clero siempre fue escasa y poco adecuada, especialmente la del regular, contra el que se levantaron las voces más críticas incluso dentro del propio estamento eclesiástico dado su protagonismo en la sociedad española y su probada ignorancia ${ }^{15}$ que le erigía en difusor de la superstición y del fanatismo, ridiculizando incluso las cosas más sagradas -recuérdese Risus Paschalis de María C. Jacobelli- ${ }^{16}$ Fue necesario editar catecismos y manuales, no siempre utilizados, para este clero no sólo mal formado, sino incluso deformado, que facilitaran la tarea solucionando casos concretos -casuismo-centrados en el sexo y en el sexto mandamiento, ${ }^{17}$ según el pensamiento de la Iglesia. Muchos autores pedían prudencia al tratar tema tan delicado. La finura, sin embargo, no fue una de las virtudes de los confesores a pesar de las penas canónicas y de las recomendaciones tanto morales como espirituales.

Segundo, se necesitaba una legislación eclesiástica capaz de atajar estos vicios. Tarea que se tomó con seriedad el Concilio de Trento (1545-1563) que trató, entre otros muchos asuntos, el tema de los sacerdotes concubinarios y de sus hijos. Pablo IV con la bula Cum sicut nuper (1559) definía la solicitación. Clemente VIII (1593) daba un nuevo paso al poner bajo la jurisdicción del Santo Oficio el delito de solicitación. Puesto que ésta no era sólo cosa de mujeres, Pablo V (1612) la ampliaba también a los hombres. Gregorio XV resolvió la casuística sobre el momento de la solicitación con la encíclica Universi Dominici Gregis (1622) y se indicaba poco después (1625) los lugares propios de confesión. ¿A qué tipo de solicitación se referían? Benedicto XIV lo aclaraba en Sacramentum poenitentiae de 1741 así como en 1745 y en 1749. La

\footnotetext{
${ }^{14}$ Vicente León Navarro, wuan Bautista Hermán: discípulo de Gregorio Mayans. Los entresijos de la curia valenciana. Una persecución en dos actos", Saitabi, $\mathrm{n}^{\circ} 48$ (1998), pp. 51-78. Gregorio Mayans y Siscar, Epistolario XIX..., pp. 36 y ss. Adelina Sarrión Mora, Sexualidad y confesión. La solicitación ante el Tribunal del Santo Oficio (siglos XVI-XIX), Madrid, 1994, p. 58. Escribe que no ha encontrado ningún proceso de solicitación en el archivo episcopal de Cuenca, al tiempo que señala que en el periodo 1740-1820 hay cierto desinterés de lia Inquisición conquense por la solicitación, p. 81 .

${ }^{15} \mathrm{La}$ obra del jesuita Francisco Isla, Historia del famoso predicador Fray Gerundio de Campazas, es un ejemplo en clave de ironía mordaz y macabra, como la del Orador Christiano de Gregorio Mayans to es en clave de utopía. Isla hace una críticu ad hominem, según Teófanes Egido (coord.), Los jesuitas en España y en mundo hispánico, Ambos Mundos, Madrid, 2004, p. 253.

${ }^{16}$ El franciscano Pedro Folques en 1811 confesaba ante el Santo Oficio que no sólo consagraba cuando y donde le daba la gana, sino que se ponía las hostias encima de la cabeza y del cuerpo e incluso las arrojaba a un pozo con el fin de santificario. En el convento de Elda llegó a arrimarse una hostia al ano limpiándose con ella y la echó al lugar cornún. Que se frotaba sus partes o suavemente la aplicaba a ellas... AUV, Varios, caja 47/12.

${ }^{17}$ Fray Valentín de la Madre de Dios, El Fuero de la conciencia... En este sentido es importante el polémico jesuita Tomás Sánchez y su obra De sancto matrimonio sacramento disputationum... A él le dedicó un número monográfico Archivo Teológico Granadino en 1982.
} 
solicitación recogía palabras, signos, gestos, tactos y todo cuanto directa o indirectamente incitase al penitente o indujese a acciones torpes antes, en o después de la confesión o con motivo de ella. Y se imponía la obligación de delatar al cómplice para obtener la absolución. Fue bastante efectivo en conciencias timoratas; muchos penitentes escrupulosos ante las penas espirituales impuestas por la Iglesia, denunciaron a los confesores solicitantes o que lo parecían. Las circunstancias propicias para estas delaciones fueron las misiones y las cuaresmas con sus confesiones generales - falsos modelos de conversión-. Estamos convencidos que muchos guardaron silencio, fuera por vergüienza, por miedo al Santo Oficio y a sus consecuencias ${ }^{18}$ o por recomendación de los propios confesores al tratarse de "cosas ocultas", como el cura de Salem a Luisa Giner en 1804. El caso más curioso es el del comisario Cabadés que sosegaba a Emerenciana asegurándole que él era ministro del Tribunal. ${ }^{19}$

No obstante tantas precauciones y ruido, los castigos solían ser benignos, predominando la suavidad, pues quienes debían castigar, aunque cautos, ${ }^{20}$ tampoco estaban exentos de los pecados de la carne, disculpando la incontinencia debido a la fragilidad humana, asumida por los propios clérigos al ser denunciados y encausados.

Las misiones, buque insignia de la catequización de la lglesia, sirvieron en ocasiones de desahogo para misioneros que, entre tanto espiritu derramado en sus atronadores y aparatosos sermones, necesitaban consuelos carnales. ${ }^{21}$ Estos fogosos hombres aprovechaban las situaciones que su trabajo les procuraba tanto dentro como fuera del confesionario. Es el caso de fray Mariano Ballester que en Cuart (1750) llevó a una moza de 18 años a casa del cura donde estaba hospedado. Empezó por sentarla en sus rodillas $y$, entre otras lindezas, le propuso cortarle los pelos de sus partes verendas para hacer reliquias. Algo similar pretendió el jesuita Joaquín Juan (1761, 45 años) con María, 28 años y casada, para acordarse de ella y tenerla siempre en la memoria. A fray Mateo Dolz, alcantarino de 35 años, confesando en Benejúzar, María León de 24 años le puso al corriente de ciertas desavenencias con sus suegros y solicitó su intervención. Tras saber dónde vivia le tomó las manos sin apenas resistencia de ella; tuvieron algunas llanezas que subieron de tono días después en su casa con contactos en partes verendas. El fraile iba con intención de gozarla. ${ }^{22}$ Tampoco se andaba por la ramas Francisco Torres en la misión de Albalat confesando a Vicenta Martínez (1775) al preguntarle: "¿Tú te has tocat les mamelles?". Ella algo sobresaltada le respondió que no. Él insistía: «Te has tocat los pits?» y sin esperar contestación: «Y la figa, ¿te la has tocat o tens

\footnotetext{
${ }^{18}$ Caso de Ara de Cólliga en Villarejo de Fuentes en 1656. Adelina Sarrión, Sexualidad y confesión..., pp. 168 y ss. José Fernández Santos, Extramuros, Seix Barral, Barcelona, 1994, pp. 48-49.

19 AHN, Inquisicion, legajo 3722/10.

${ }^{20}$ Gérard Dufour, Clero y sexto..., p. 78.

${ }^{21}$ Carta de Hermán a Mayans 16 de enero de 1757 , Gregorio Mayans y Siscar, Epistolario XVIII...

${ }^{22}$ AUV, Varios, caja 55/1. Año 1747.
} 
en ella algú molet?» y aclaraba por si acaso: «Si te has tocat les teues parts». ${ }^{23} \mathrm{~A}$ estas fragilidades no escapaban ni los ministros del Santo Oficio ni los catedráticos de la Universidad, como es el caso del mercedario Cabadés, que estudiaré aparte. Fray Antonio Personat, que con ocasión de predicar en la Cuaresma de 1804 se alojó en casa de Luisa Giner de 37 años y casada, quiso aprovechar situación tan privilegiada para solicitarla y ante su resistencia le espetó: «Vd. se hace pencas y ahora ha venido una a confesar y me ha dicho que un fraile se lo había hecho tantas veces». ${ }^{24}$

Los intentos de atajar la solicitación menudearon, pero los resultados fueron pobres. Poco miedo inspiraba el Santo Oficio cuando ni siquiera las penas del infierno eran capaces de retraer a algunos ardientes clérigos de su pasión carnal. El Antídoto para solicitantes, aparecido sin nombre ni censura teológica ni licencia, se presentaba como una solución. ${ }^{25}$ Fue prohibido. Dos censuras, una de 1778 y otra de 1793 , señalan la inconveniencia de su impresión y circulación puesto que sin aportar nada positivo sí revelaba procedimientos del Santo Oficio que no convenía que el vulgo conociera como la situación de las cárceles o la idea de que sólo solicitaban los regulares. Más que formar deformaba dando armas a los enemigos del Tribunal y de la Iglesia.

\section{La Inquisición.}

La Inquisición española, nacida en el siglo XIII, adquiría nueva relevancia y extensión como entidad supranacional bajo los Reyes Católicos, empeñados en la uniformidad religiosa, para luchar contra la herejía nacida a la par que la religión. ${ }^{26} \mathrm{Su}$ inmenso poder se mantuvo incólume hasta el año 1808 en zona francesa y hasta el 1813 en zona patriota. Fernando VII la restableció con gran regocijo de la Iglesia (21-VIII1814) como pilar básico del orden social y de su monarquía contra liberales y afrancesados símbolo de todos los males. El moderno Tribunal, que contaba con detractores, venía a fortalecer la religión verdadera con la ayuda del brazo político. ${ }^{27}$ Omnipresente condicionó y controló la sociedad, la vida privada de las personas hasta los más recónditos rincones, ${ }^{28}$ reprimió fanáticamente y castigó la posible heterodoxia de los disidentes, fueran cristianos, moros o judíos. Censuró y prohibió libros y se rodeó đel aura del misterio, del secreto y del miedo gracias al degradante sistema de delación y acusación

${ }^{23}$ A pesar de las prohibiciones de usar el valenciano, algunos clérigos continúan usándolo con asiduidad. AUV, Varios, caja $61 / 14$.

25 AUV, Varios, caja 69/8. Este franciscano de Benigànim tenía 30 años.

${ }^{25}$ Gérard Dufour, Clero y sexto..., p. 86.

${ }^{26}$ Juan Antonio Llorente, Historia crítica de la Inquisición en España, Libros Hiperión, Madrid, 1980, vol. I, p. 31 . Sobre sus origenes hay una amplia bibliografia, entre las que destaca la del propio Liorente.

27 Bartolomé Benasar, Inquisición española: poder político y control social, Crítica, Barcelona, 1984.

${ }^{28}$ Vicente León Navarro, La pasión por la libertad. Miguel Cortés y López (1777-1754). Diputado a Cortes y Diputado Provincial, Biblioteca Valenciana, Valencia, 2003, pp. 57 y ss. 
que potenció sirviéndose del pecado mortal, de la excomunión y de la pena eterna. Inspiró miedo y terror sin que nadie quedase fuera de sus cristianas, caritativas y afiladas garras, laicos y eclesiásticos, hombres y mujeres, pobres y ricos, obispos y curas, frailes y monjas, casadas y beatas, nobles y plebeyos, intelectuales e iletrados, siempre por el bien de las almas a las que perseguía al tiempo que maltrataba los cuerpos, ${ }^{29}$ despreciando no sólo el más elemental derecho natural sino también humano. Todo era lícito en nombre de dios — de su dios-, de la religión — su religión - y de la iglesia, —su iglesia-. Se servirá de la hipocresía manejada con astucia para marear al reo y hacerle creer lo que no es con el perverso fin de que confiese. ${ }^{30}$ De ahí las palabras de Peña al inicio de Manual de Inquisidores:

La finalidad de los procesos y de la condena a muerte no es salvar el alma del acusado, sino mantener el bienestar público - y buen orden moral, podríamos añadis nosotros-y aterrorizar al público.

En oposición a estos planteamientos Cornelia Bororquia era una loa a la tolerancia. ${ }^{31}$ Llorente la tachó de fábula calumniosa ${ }^{32}$ y mostraba ciertos reparos a muchas denuncias fundadas más en la imprudencia que en la mala conducta de algunos confesores. $^{33}$

Es cierto que el Santo Oficio, odioso por sí mismo, a lo largo del XVIII fue perdiendo peso en la sociedad de forma gradual gracias al control real -regalismo enfrentado a la Curia romana-, al castigo a los inquisidores generales, a la imposición del exequatur regium, a las Cédulas sobre la bigamia, a la limitación de la jurisdicción de los familiares del Tribunal y a la propia evolución social. Estos aspectos socavaron un prestigio que se quiso mantener con casos tan sonoros como ejemplares de los Macanaz u Olavide y la permanente censura de libros. García Cárcel ha visto el influjo que tuvo la disminución de las rentas en esta decadencia y la imposibilidad de premiar bien al personal, recurriendo a ministros cada vez menos cualificados. ${ }^{34}$ Llovía sobre mojado, las nuevas corrientes ideológicas atacaron directamente la línea de flotación del Tribu-

\footnotetext{
${ }^{29}$ José Joaquín de Clararrosa, Viaje al mundo subterráneo y secretos de la Inquisición revelados a los españoles, edición, introducción y notas de Daniel Muñoz y Beatriz Sánchez Hita con prólogo de Alberto Gil Novales, Salamanca, 2003.

${ }^{30}$ Juan Antonio Lorente, Historia crítica..., pp. 243 y ss., vol. I. Juan Pablo Forner, Discurso sobre La tortura, edición de Santiago Mollfulleda, Crítica, Barcelona, 1990. José Joaquín de Clararrosa, Viaje...

${ }^{31}$ Cornelia Bororquia a la victima de la Inquisición, edición, introducción y notas de Gérard Dufour, Alicante, 1987.

${ }_{32}$ Juan Antonio Llorente, Ibídem, p. 227.

${ }^{33}$ Id., pp. 29-33, vol. III.

${ }^{34}$ Ricardo García Cárcel, «Las rentas de la Inquisición valenciana en el siglo XVIII, Estudis, $\mathrm{n}^{\circ} 4$ (1974). Juan Antonio Lorente, Historia crítica...; lamenta la ausencia de formación adecuada del personal del Santo Oficio. El elenco bibliográfico es numeroso.
} 
nal y su razón de ser, ${ }^{35}$ gracias a ministros, intelectuales, nobles, burgueses, economistas, clérigos - labor importante desempeñaron los últimos Inquisidores Generales-, etcétera, cada uno desde su parcela guiados por las luces y las reformas o simplemente por un ideal cristiano primigenio. Todos condenaron con más o menos fuerza un Tribunal inhumano, anticristiano, infernal y propio de pueblos bárbaros, ignorantes y embrutecidos fanáticos. Añoraban la Iglesia primitiva y una implicación mayor de los obispos en la defensa de su jurisdicción. Las críticas arreciaron a lo largo del siglo en la medida en que se debilitaban de forma inexorable las estructuras del Antiguo Régimen (Roda, Campomanes, Azara, León de Arroyal, Valentín de Foronda, Jovellanos, Cabarrús...), como demuestra la amplia bibliografía.

La Inquisición no podía dejar a nadie indiferente. ${ }^{36}$ Defensores y detractores hicieron correr ríos de tinta sacando a relucir, unos, su crueldad o fanatismo intolerante, como Clararrosa desvelando sus secretos, ${ }^{37}$ Puigblanch exigiendo su abolición, ${ }^{38}$ Bernabeu celebrando la felicidad española con su muerte, ${ }^{39}$ o Luis Gutiérrez achacando a este «diabólico tribunal» todos los males. ${ }^{40}$ Otros defendieron su necesidad. ${ }^{41}$

Desde el momento en que Clemente VIII puso la solicitación bajo la jurisdicción del Santo Oficio, las cosas empezaron a cambiar. Los confesores solicitantes quedaron inmersos en la sospecha de herejía y fueron muchos los que se vieron envueltos en largos, penosos y complejos procesos penales, gracias, en parte, al secreto con que trabajaban los ministros del Tribunal y a la lentitud de su pesada maquinaria. Los reos solían desconocer la acusación y a los delatores; si se encontraban indicios de culpabilidad se les privaba de confesar y predicar y en muchos casos de sus bienes para hacer frente a los gastos procesales. El miedo a la acusación les inducía a delatarse de forma espontánea, más para suavizar el castigo que por arrepentimiento, recurriendo incluso a la compra de testigos, caso de Florián Fuster en $1707^{42}$ y a las coacciones. Es cierto

${ }^{35}$ Seria muy larga la nómina de personas y de investigadores que han trabajado en ese punto, tanto españoles como extranjeros. Valga señalar que España fue receptora de todas las corrientes europeas, especialmente italianas, francesas, inglesas, alemanas... Gregorio Mayans fue un ejemplo.

${ }_{36}$ Antonio Álvarez de Morales, «La crítica al Tribunal de la Inquisición durante la segunda mitad del siglo XVIII", Estudis, n' 6 (1977).

${ }^{37}$ José Joaquín de Clararrosa, Viaje al mundo...

${ }^{38}$ Puigblanch, La Inquisición sin máscara o disertación en que se prueba hasta la evidencia los vicios de este Tribunal y la necesidad de que se suprima, estudio preliminar de Abelló Juanpere, Imprenta de José Niel, Cádiz, 1811-13. Nueva edición, Altafulla, Barcelona, 1988. Jovellanos pedia a Carlos IV en 1798 pasar la jurisdicción inquisitorial a los obispos. Por su parte Marchena en $A$ la Nación española en 1792 abogaba por su supresión total. Miguel Cortés considera al Tribunal incompatible con la Constitución y a sus ministros ignorantes y fanáticos, en Vicente León Navarro, La pasión por la libertad...

${ }^{39}$ Antonio Bernabeu, España venturasa por la vida de la Constitución y muerte de la Inquisición, Imprenta Repuliés, Madrid, 1820.

${ }_{40}$ Claude Morange, Siete Calas en la crisis del Antiguo Régimen español, Alicante, 1990, pp. 277-400.

41 Javier Herrero, Los origenes del pensamiento reaccionario español, Alianza Bd., Madrid, 1994.

${ }^{42}$ AUV, Varios, caja 48/1. 
que el tribunal jugaba maquiavélicamente con el secreto, obligando al reo a confesar todo, pero no se mostraba muy severo. Tal vez Eymerich dé la explicación: «No hay que mostrarse muy celoso en perseguir a religiosos y sacerdotes pues el proceso a un sacerdote puede interpretarse como proceso a todo el cleron. Comprensión hacia estos solicitantes a los que se les acomodaba en conventos y se les imponía penas llevaderas si exceptuamos el daño moral al prohibirles confesar y predicar. ${ }^{43}$

\section{¿Uso personal del Santo Oficio?}

Que el Tribunal no fue ajeno a los intereses políticos ni tampoco personales lo demuestra el caso de Juan Mallent, beneficiado de la parroquia de San Juan (1748), acusado de solicitación y mala doctrina con sentencia definitiva en 1748 , privado de confesar hombres y mujeres, recluido seis años primero en el convento de Recoletos y luego en el de Sancti Spiritus. Al mes elevó un memorial al Inquisidor General, Francisco Pérez de Prado, exponiendo su situación y pidiendo poder seguir confesando en el Hospital General. Se le permitió y fue trasladado al convento de la Corona de Valencia donde tuvo algunos problemas; solicitó su reintegro a Sancti Spiritus, cuyo guardián en varias ocasiones escribió al Tribunal sobre su mal comportamiento y menosprecio de las advertencias que se le hacían. Era un mal ejemplo para la comunidad. Fue desterrado a Turís a principios de 1751 desde donde escribió otra vez al Inquisidor General. Ya en Valencia se dirigió al Consejo y su abogado Antonio Ordóñez pidió conocer su causa, que ya su hermano había aireado por la Corte. ¿Qué había sucedido? Mallent acusaba al secretario del Santo Oficio de Valencia, Manuel Mayans, a quien su hermano Gregorio apreciaba más bien poco. ${ }^{44}$

Según Mallent, Mayans actuó con malevolencia. Parece ser que Sebastiana Fortea, una de las acusadoras de Mallent, servía en casa de éste, de donde salió a la de Vicente Sebastián íntimo de los Mayans. Otra criada abandonó también por este tiempo la casa del cirujano Borrell yendo a servir a la de una viuda que visitaban Mallent y ciertos religiosos. Borrell difundió el rumor de que éstos reunian a sus confesadas «para hacer mejor sus gustos». La noticia llegó al Santo Oficio que nombró una comisión, uno de sus miembros, Vicente Sebastián, interrogó a Sebastiana, igual que a otras confesadas, por los asuntos de Mallent. Los miembros de la comisión convinieron que el rumor era

${ }^{43}$ Juan Antonio Lorente, Historia critica..., p. 21, vol. III.

4 Manuel Mayans habia ingresado en el monasterio de la Valldigna; abandonó la Orden y su hermano Gregorio le consiguió, siendo bibliotecario real, la secretaría del Santo Oficio por medio de Andrés Orbe. Según Amparo Alemany, Manuel sembró cizaña en la familia para impedir la boda de Gregorio con Margarita y parece que Manuel pretendió hacerse con toda la herencia, una de las posibles razones de la vuelta a Oliva en 1739 del erudito. Amparo Alemany Peiró, Juan Antonio Mayans y Siscar (1717-1801). Esplendor y crisis de la Ilustración valenciana, Ayuntamiento de Oliva, Valencia, 1994, pp. 31, 55 y 59. 
falso, excepto Vicente Sebastián. El proceso continuó, aumentando la animadversión que, de acuerdo con Mallent, tenía su origen en un asunto personal. Don Antonio, hermano de don Manuel, que aspiraba a la vice-rectoría de la parroquia, pidió el voto a Mallent quien se lo negó alegando su avanzada edad. Este desaire irritó a los Mayans y don Antonio le acusó de mal sacerdote, de andar por la casa de sus confesadas y prometió perderle por el confesionario. Mallent le tachó de viejo y de loco. Aumentó pues la enemistad. Los Mayans y sus amigos buscaron el modo de hacerle daño, encontrando en Sebastiana, forzada por ellos, una aliada que se prestó al principio al juego acusándole de solicitante, al igual que las otras confesadas. El secretario Mayans detuvo al reo personalmente con mucho alboroto (solía hacerse en secreto), llevándole preso como si se tratara de un delincuente. En la audiencia negó las acusaciones, siendo reprendido por el inquisidor Espinosa por atreverse a culpar a los ministros del Santo Oficio. Se le nombro abogado que le dejó indefenso, ${ }^{45}$ siendo condenado sin suficientes pruebas. La causa, llevada por su hermano Manuel Mallent, se vio en el Consejo que lo remitió al Tribunal de Corte donde se tenía constancia de que este hecho había sido dispuesto por Manuel Mayans a su satisfacción contando con la ayuda del duque de Alba, Francisco Zepeda y Manuel Pablo de Salzedo. El asunto levantó una gran polvareda. Mallent intentó, por todos los medios, restablecer su honor ya que los testigos habían confesado plegados los intereses de Mayans y Sebastián. Varios hombres de la vida valenciana dejaron oír sus opiniones como el padre Nebot, el canónigo Felipe Musoles, el deán Tomás Grau o el canónigo Casamayor y expresaron sus dudas sobre la culpabilidad de Mallent, desconfiando de la rectitud de Manuel Mayans, (el Palmerino) y de Vicente Sebastián (el Bou). No obstante, el 11 de noviembre de 1756 el Consejo condenaba a prisión al reo; el Santo Oficio era el Santo Ofício. Las dudas sobre la limpieza del proceso y el abuso de poder por parte de los ministros del Tribunal no desaparecieron. Odios y pasiones denunciaba ya Fernando del Pulgar en su Crónica de los Reyes Católicos ${ }^{46}$ y nosotros podríamos ampliar con documentos referentes a la Guerra de Sucesión y a la de la Independencia y a las visiones sobre el poderoso Godoy, pero sobrepasa ya este trabajo. ${ }^{47}$

45 José Joaquín de Clararrosa, Viaje al mundo..., pp. 132 y ss. Juan Antonio Lorente, Historia critica..., p. 236 , vol. I.

${ }_{46}$ Juan Antonio Lorente, Historia crítica.., p. 185, vol. I. Id., p. 99, vol. IV, Vicente León Navarro, La pasión por la libertad..., pp. 57 y ss.

${ }^{47}$ Carmen Pérez Aparicio, «El clero valenciano a principios del siglo XVIII: la cuestión sucesoriu», Estudis de Historia Moderna de Valencia (1978), pp. 247.84. Sacrilegios y profanaciones cometidas por los soldados y tropas del Archiduque en Castilla, años de 1706 y 1710, Madrid, 1711. Ver los datos que aporta Gérard Dufour en Clero y sexto..., pp. 13-14. AUV. Varios, cajas $70 / 8$ y $49 / 2$. 


\section{El drama humano del celibato.}

No se insistirá bastante en la situación humana de un colectivo que llevado voluntaria o forzosamente a la vida eclesiástica acepta el celibato impuesto por la Iglesia para formar parte especial de ella, frente a quienes, no pudiendo prescindir de los placeres de la carne, se casan. Los casados, mancillados por el sexo, pertenecen a un nivel inferior, ${ }^{48}$ pues es incompatible la perfección con el matrimonio. Desde antiguo ha constituido un elemento de debate a pesar de los intentos de Letrán I - y otros Concilios-y Trento de dejar las cosas claras beneficiándose la Iglesia del clero célibe, ${ }^{49}$ pero haciendo la vista gorda respecto a sus comportamientos sexuales siempre y cuando no afectaran al tribunal de la penitencia. ${ }^{50}$ Por una parte denuncia el sexo y lo condena como el origen de todos los pecados y, por otra, ningún clérigo escapa a sus encantos. ${ }^{51}$ El sacramento no era un remedio contra la lujuria, mas bien el matrimonio era una fuente de placer y deleite, muy lejos del idealizado amor divino. ${ }^{52}$

Si nos remontamos a los primeros siglos del cristianismo encontramos en Pablo de Tarso, un judío imbuido del Antiguo Testamento con su carga negativa respecto al pecado y a la mujer —que se ve en el Eclesiastés, 25,24 , un poderoso referente para la Iglesia posterior, tomándole como modelo. Pablo habla a veces en nombre propio y otras en nombre del Señor que le ha hecho ver la verdad, y ante cuestiones planteadas por sus seguidores en tiempos de crisis y de dificultades, contesta puntualmente como un converso que espera la inminente venida del Señor: «Os digo, pues, hermanos; el tiempo es corto. Por tanto, los que tienen mujer vivan como si no la tuviesen» (I Cor., 7, 29). Precepto que se aplicará más tarde a cuantos casados acepten el estado clerical, como en el concilio de Nicea del año 325. No desdeñen a sus mujeres, dice, pero tampoco tengan parte con ellas pues hay que estar preparados. $Y$ a esto sc dirigen sus palabras del capítulo 7. Él mismo quiere ser ejemplo; no obliga, pero advierte que nadie se preocupe de cambiar nada en orden al matrimonio o a la virginidad que, precisa, no es precepto divino sino ley humana. No hay pecado en el matrimonio ifaltaría más! pero los casados tendrán su tribulación en la carne que él quiere evitar. La doctrina paulina en este punto es poco practicable y dirigida a unos cuantos seguidores que esperan la parusía del Señor (I Tesal., 5), ante la que se levantarán falsos profetas y habrá señales

\footnotetext{
${ }^{48}$ Georges Duby, El caballero, la mujer y el cura, Taurus, Madrid, Ed. de 1982, p. 27.

${ }^{49}$ M. Foucault, Historia de la sexualidad. 1. La voluntad de saber, Madrid, Siglo XXI, 1995, p. 16.

50 Vicente Salvá, La bruja o cuadro de la Corte de Roma, Paris, 1830. Edición que prepara Germán Ramírcz Aledón. Alusión a Roma convertida en un lupanar.

${ }^{51}$ Caso de Arce y su hipocresía. Gérard Dufour, «Don Ramón de Arce, arzobispo de Zaragoza, Patriarca de las Indias e Inquisidor General», Tres figuras del clero afrancesado, Université de Provence, 1987.

${ }_{52}$ María Luisa Candau, «El amor conyugal, el buen amor. Joan Estevan y sus "avisos de casados" Historica. Historia Moderna, $\mathrm{n}^{\circ} 25$ (2003), pp. 311-349.
} 
(II Tesal. y II a Timoteo). Este fanatismo paulino tomado al pie de la letra constituye la base de la doctrina de la Iglesia que asocia sexo-mujer-pecado. Se equivocaba Pablo, hombre de su tiempo y de las circunstancias concretas de su formación y de su conversión, al hacer coincidir santificación con castidad y pureza (I Tesal., 4, 3-8). Ahí queda la herencia y sus frutos.

La historia de la Iglesia es la del drama humano que, a través de sus doctrinas, ha influido tanto en clérigos como en fieles. Unos hombres que, incapaces de sublimar su sexualidad, como pedía san Pablo, necesitaban manifestarla aprovechándose de la confesión y de su autoridad de clérigos administradores del misterio, contradiciendo así sus propias enseñanzas y las de la Iglesia a la que servían. Ciertos confesores restaban importancia a lo que decían o hacían, negando el pecado con el fin de influir en sus penitentes..$^{53}$ Así el franciscano Mathes (Denia 1787) tuvo tocamientos con Antonia Moreno a la que aconsejaba que cuando volviera a confesarse no hablase de ello «que no hiciese caso, que iba a su cargo». Rafael Sigüenza, franciscano de Onil, justificaba los tocamientos a Margarita de 20 años y a sus hermanas con «que aquello no lo tenía por pecado, que era fugaz... que era juego, que si ellas no querían no pecaban».54 Qué sentido tenían del pecado carnal unos confesores que lo monopolizaban, que abusaban de su autoridad y que les traía de cabeza el sexo, a veces por amor, otras por necesidad física y algunas por afectividad propia de la naturaleza humana y de la crisis de los cuarenta debido a su soledad, a la monotonía de la vida religiosa, a la falta de perspectivas y a los atractivos de la vida secular. ${ }^{55}$ Florián Fuster, vicario de Villarreal, enviaba a su criada Josefa a casa de Matilde para tener actos con ella, mientras ocultaba los embarazos de Josefa a la que preparaba potingues para hacerla abortar. No era la primera vez y acabó casándola con Jerónimo para salvar su imagen. También resultó ser el autor de varios embarazos de su criada el beneficiado de la catedral de Segorbe,

\footnotetext{
${ }^{53}$ Para el franciscano Mariano Pérez «el fornicar hombres y mujeres no es pecado». Que «el hombre no saca más de este mundo que lo que se divierte con la mugeres y el gusto que se tiene cuando se junta con ellas. Que en esta materia Dios nos pedirá quentas por si hemos estado ociosos y no hemos hecho uso, porque a lo último la tierra lo ha de podrir todo». AUV, Varios, 71/8. P. Conard, «Sexualité et anticlericalisme», Hispania, n'31 (1971), pp 103-131.

${ }_{54}$ AUV, Varios, caja 64/5. Cuadra con el texto de La Celestina que expresa que el goce de la mujer hermosa no es pecado, pecado es que la mujer no deje al prójimo disfrutar de su cuerpo. Citado por Enrique Gacto, «Inquisición y censura en el barroco», Sexo barroco y otras transgresiones premodernas, Alianza Universidad, Madrid, 1990, p. 163. En esta línea el diálogo de un confesor y una niña arrepentida de su delito de amar que no piensa repetir. «Eso sí que es gran delito/ no le absolveré jamás», responde el confesor. AHN, Inqquisición, legajo 4450, an̆o 1806. Jesús Fetnández Santos, Extramuros, p. 48.

${ }^{55}$ Stephen Haliczer, Sexualidad en el confesionario. Un sacramento profanado, Siglo XXI, Madrid, 1998, p. 161. Decía José Padilla a las mozas sentadas a la puerta del convento de agustinos de Valencia para hacer labor: "Chicas, vosotras estáis bien que dormís en compañía; pobre de los frailes que dormimos solos»; a lo que contestan ellas: «Lo mismo puede bacer Vd. dumiendo con algún fraile». «Bueno está, dijo él, con eso no tengo yo ganancias. Juan Antonio Lorente, Historia crítica...; cuenta la interesante y pícara historia del capuchino de Gayanes (Alicante). Vol. III, pp. 33 y ss. Hay muchas más.
} 
Miguel Fuster. Algo corrido andaba el beneficiado de Ababug (1768) cuando solicitó y tuvo acceso carnal con María, 16 años, que encontró sacando el cieno de una paridera. Acto que repitió asegurándole que no se quedaria preñada si no lo hacían por lo menos 6 ó 7 veces. ${ }^{56}$ Francisco Gil fue denunciado por su conducta escandalosa y lasciva con una doncella de Barracas. ${ }^{57}$ Otros querían dar estabilidad a las posibles relaciones como el franciscano Juan Monserrat (1759) en Valencia cuando prometía a María Monllor, al tiempo que abrazaba a tía y a sobrina, que si se fuera a vivir con él buscaría retoría y la tendría con estatuto de sobrina. Y mientras le tocaba sus partes por encima de la ropa añadía: «Toda eres mía, higa y todo»..$^{58}$ La sexualidad reprimida necesitaba sus desahogos y había que buscarlos, contando con la comprensión de la autoridad eclesiástica, pero evitando la publicidad que escandalizaría a los fieles. ${ }^{59}$

Por ello el matrimonio del clero se ha planteado siempre como remedio a estos males que no ignoraba José Luis de los Perales en 1901, quien no obstante defendía la castidad idealizando al sacerdote cuyo «lecho cubre la flor de la virginidad». ${ }^{60}$ Posiblemente era la réplica al libro del sacerdote Juan Villada a favor del matrimonio del clero. ${ }^{61}$ Clero que se gloriaba de vivir en la continencia cuando era raro el que no tenía manceba o mujer. ${ }^{62}$ Es imposible vivir con mujer y no pecar (milagro según San Bernardo) cuando se permite tener mujer, incluso hermosa, pero no prole, escandalizando al pueblo que ve estos modos de vida impúdicos e inmorales. Villada pedía liberar al clero de esta esclavitud permitiendo la elección de estado, como ya pidieran otros anteriormente, entre ellos Juan Antonio Llorente. Y es que la vida de los clérigos raramente se ha ajustado a las normas eclesiásticas, siendo motivo de críticas acerbas, ${ }^{63}$ a pesar de las continuas reformas. ${ }^{64}$ En su contra han jugado factores como su elevado número, los odios teológicos, su poder para intervenir en todos los asuntos, su degradación continua, etcétera. ${ }^{65}$ Ante estos comportamientos clericales se ha desarrollado desde siempre una

${ }^{56}$ AUV, Varios, caja 60/5.

57 AUV, Varios, caja 60/1.

${ }^{58}$ AUV, Varios, caja 57/10. Franciscano de 55 años.

${ }^{59}$ Juan Antonio Llorente, Historia crítica..., vol. III, p. 22.

${ }^{60}$ José Luis de los Perales, El clero y el siglo, Imprenta de F. Martín Tapia, Madrid, 1901.

${ }^{61}$ Juan Villada, Matrimonio del clero, Valladolid, 1896. No son pocas las réplicas de mujeres que afean las solicitaciones y por qué habían tomado el estado sacerdotal. Teresa, de 18 años y casada, a fray Juan Bautista Catalá cuando éste la perseguía diciéndole «que se lo tenía que dar». AHN, Inquisición $3722 / 60$.

${ }^{62}$ Ver los trabajos de B. Barreiro Mallón publicados en Compostellanum XXXII (1988) y XXXVI(1990). Me remito también a mis trabajos sobre las visitas ad limina.

${ }^{63}$ Barón d'Holbach, Les prêtes démasqués ou des iniquités du clergé chrétien, London, 1763. Maximiliano Barrio, «El clero regular en la España de mediados del siglo XVII a través de la "encuesta de 1764"», Hispania Sacra, $\mathrm{n}^{\circ} 47$ (1995), pp. 121-169.

${ }^{64}$ Antonio Luis Cortés Peña, La política religiosa de Carlos II, Universidad de Granada, 1989.

${ }^{65}$ Manuel Revuelta, Política religiosa de los liberales en el siglo XIX, CSIC, Madrid, 1973, p. 46. Antonio Mestre, Ilustración y reforma..., pp. 239 y ss. Enrique Jiménez - Mario Martínez, «El episcopado español y la encuesta del Marqués de la Ensenada de 1750», Iglesia, Sociedad y Estado en España, Francia e Italia (ss XVIII al XX), edic. de Emilio La Parra y Jesús Pradells, Alicante, 1992, pp. 263-300. 
actitud crítica anticlerical que he intentado sintetizar en otro trabajo ${ }^{66}$ y que adquiere especial relevancia en éste al relacionar confesionario, sexo y anticlericalismo. Gérard Dufour ha visto bien esta conexión ${ }^{67}$ El confesor por su oficio tiene acceso íntimo a las conciencias de las mujeres, de cuyos secretos es depositario, provocando recelo y animadversión entre los hombres que se sienten marginados, excluidos y preocupados por esa proximidad física tanto en como fuera de la confesión. Entre la mujer y el confesor quedan los secretos que nadie más debe conocer. En este sentido Álvarez Junco pone el dedo en la llaga al subrayar que «machismo y, por tanto, rivalidad por el dominio del mercado erótico parecen tener en la base del anticlericalismo mayor importancia de la que suele reconocerse $\gg .{ }^{68}$ Así se manifiestan D. D. Gilmore ${ }^{69}$ y Delgado Ruiz, ${ }^{70}$ quien subraya la complicidad de la Iglesia y su interés en ocultar una realidad molesta y que la sociedad ha visto y vivido en toda su crudeza. Quizás fray Ambrosio se admiraba en 1792 de que «se vivía en unos tiempos en que cada día van los seglares perdiendo más el respeto y veneración que sus antecesores tuvieron a los eclesiásticos $\$ 7^{71}$ coincidía con el obispo de Segorbe. ${ }^{72}$ La explicación la daba Antonio Gavin en su Master Key to Popery al denunciar la solicitación en confesión y la influencia negativa de los confesores en las familias gracias a las mujeres. La Familia de León Roch es un ejemplo. ${ }^{73}$ Hay casos en que los maridos riñen con sus mujeres y prohíben a los clérigos entrar en sus casas, ${ }^{74}$ pero son muchos los que aprovechan las ausencias de los hombres para hacer las visitas a domicilio con excusas diversas pero finalidad clara.

No descartamos la iniciativa de la mujer que busca en el confesor consuelo, apoyo y dirección espiritual y emplea sus irresistibles armas seductoras. El confesor es visto como el rival del marido, del novio o del amante contra el que no se puede luchar con las mismas armas y, por tanto, se odia su privilegiada situación que le permite conocer,

${ }^{66}$ Vicente León Navarro, «Violencia clerical-anticlerical...".

67 Gérard Dufour, Clero y sexto... Fray Valentín de la Madre de Dios, Fuero de la conciencia...

68 J. Álvarez Junco, eEl anticlericalismo en el movimiento obreros, Octubre de 1934. Cincuenta años para la reflexión, Madrid, Siglo XXI, 1985.

${ }^{2}$ D. D. Gilmore, «The anticlericalism of the andalusian rural proletarians», La religiosidad popular. I Antropología e Historia, C. Alvarez Santaló, María Jesús Buxó y S. Rodríguez Becerra (coords.), Barcelona, Anthropos, 1989 , pp. 478-498.

${ }^{70}$ Delgado Ruiz, al.a intirreligiosidad popular en España», La religiosidad..., p. 507; Francisco Fajardo Spinola, "Confesores solicitantes en Canarias. (Siglos XVI-XVII)", Disidencias y exilios en la España moderna, Antonio Mestre y Enrique Jiménez (eds.), Alicinte, 1997, pp. 591-600.

7 AUV, Varios, caja $66 / 3$.

12 Vicente León Navarro, «Cara y cruz...», p. 14; Id., «Popolo e religione nella visite ad limína del vescovi di Valencia (1750-1868). Un processo di secularizacioner, Stato, Chiesa, e Societá in Italia, Francia, Belgio e Spagna nei secoli $X I X \cdot X X$, Foggia, Bastogi, 1993.

7 Jules Michelet, Consejos a los jesuitas y Jean Pauper, La corrupción de un confesor, F. Semper y Compañía, traducción de $M$. Inyesta, Valencia, s/a.

${ }^{4}$ Fray Ambrosio cerrándose en las casas con las mujeres era causa de que los maridos riñesen con ellas. AUV, Varios, caja 65/1. El marido de Salvadora Zerdá prohibe al cura de Castell que entre en su casa por sospechas (1759). Onofre Barberá ordena al cura Noalles que no visite más a su hija (1735). 
controlar y abusar del penitente. El marido, novio o amante tiene la sensación de compartir con otro la posesión de la mujer. La Regenta de Clarín es, tal como lo ve María Luisa Cerrón, un ejemplo de esa lucha por la mujer entre dos hombres, el confesor y el amante; no duda en llamar a esta obra la novela de la confesión, que permite ver esa «educación espiritual católica que se agota en el estéril control de las almas a través de la práctica de la confesión auricular». ${ }^{75}$ Para Haliczer La Regenta representa una meditación irónica sobre el sacramento de la penitencia y el papel del confesor. ${ }^{76}$ Parece quedarse corto. Para Clarín, el confesor, aquí don Fermín, encarna todos los vicios; es la imagen negativa de la Iglesia y de la religión. El clero, que controla y dirige la persona hacia un supuesto bien superior, está sujeto a las pasiones más vivas a las que no puede renunciar. Es ahí donde tiene lugar la batalla en la que la mujer representa la gloria del placer y el demonio, dominada y dominadora, víctima de una educación que tan bien representa Moratín en La Mojigata y en El sí de las Niñas o Michelet en Le prête, la femme et la famille. Mojigata es también la protagonista de La familia de León Roch que novela Pérez Galdós con pleno acierto, destacando, como señala Pérez Gutiérrez, su anticlericalismo, su crítica a la intolerancia y esa rigidez moral e hipócrita en la que el magisterio clerical no aboga por el amor y la generosidad sino por la autosatisfacción, el fanatismo y el formalismo nada evangélico. ${ }^{77}$ No se busca una mujer instruida sino virtuosa, esto es, obediente, baluarte de la fides avita y punta de lanza clerical en la familia. Al final queda la duda sobre la validez de estos planteamientos religiosos y su base popular que recoge Clarín en Preludios ${ }^{78}$ y encontramos en otros documentos. ${ }^{79}$

\section{Solicitación en el confesionario.}

La confesión auricular obligatoria aumentó, pues, el poder del confesor, especialmente sobre las mujeres, sin descartar a los hombres, consideradas más vulnerables, inclinadas a las prácticas de devoción y al confesionario, como apunta Michelet. La visita a la iglesia es un escape, una necesidad de salir del estrecho círculo doméstico, de la rutina y la confesión una práctica necesaria en esa dialéctica entre pecado-absolución, entre paz y guerra espiritual, entre perdón y castigo, entre salvación y condenación que atribula la conciencia de forma continua, al menos aparentemente. A pesar de los

\footnotetext{
${ }^{75}$ María Luisa Cerrón, «Las confesiones de Ana. Modelos de introspección en La Regenta de Clarín», Cervantes, $n^{\circ} 1$ (2001), pp. 143-144.

${ }^{76}$ Stephen Haliczer, Sexualidad en el..., p. 280.

${ }_{77}^{7}$ F. Pérez Gutiérrez, El problema religiaso en la generación de 1868, Taurus, Madrid, 1975, p. 230.

${ }^{78}$ Leopoldo Alas, Preludios de 'Clarin', estudio, selección y notas por Jean-François Botrel, Oviedo, Instituto de Estudios Asturianos, 1972, pp. 26-27.

${ }_{79}$ AUV, Varios, caja 64/3.
} 
avances del siglo XVIII ${ }^{80}$ la mujer no refleja su auténtica fuerza en la estructura social, ${ }^{81}$ lo que no le impide ser objeto de los ataques más furibundos por parte de predicadores y moralistas, identificándola con el demonio. Su sola presencia es causa de pecado, sea por su forma de vestir, de mirar, de andar o de hablar. ${ }^{82}$ Los obispos no se cansan de publicar Edictos y Cartas Pastorales en este sentido. Algunos rigoristas como Felipe Bertrán, José Climent o Armayná, por citar algún ejemplo, condenan su inclinación al lujo - que no conviene ni social ni económica ni espiritualmente-, a los afeites y peinados, a mostrar sus encantos físicos en la calle, en la iglesia o en cualquier lugar, poniendo en peligro la salvación, pues ¡qué pocos se salvan! escribía Bertrán. ${ }^{83}$ Más devoción, exigían estos hombres preocupados por el bien de las almas. La mujer enciende pasiones, y no espirituales precisamente, es la tentación misma, fuente de deseo lujurioso, dirá el padre Arbiol, que trastoca el orden social y atenta contra la pureza de los clérigos dentro y fuera del confesionario. ${ }^{84}$ ¡Cuánta literatura religiosa sobre este tema! Sin embargo, la moral popular estaba lejos de estos planteamientos rigoristas. Hay una tendencia finisecular hacia la relajación de las costumbres en su sentido más hedonista en la medida en que la Iglesia lenta pero inflexiblemente pierde peso social, ${ }^{85} \mathrm{se}$ implantan corrientes teológico-morales más laxas y gana terreno la secularización.

El miedo a la mujer como el veneno de Dios ${ }^{86}$ y su condena como inductora al pecado, encontraba también su lado positivo. En casi todos los procesos estudiados las declaraciones de las penitentes, a pesar de la misoginia clerical, se tenían por dignas de crédito y veraces. Se trataba de mujeres de buenas costumbres y así debía ser después de los informes exhaustivos a que eran sometidas y a los datos que se les pedía sobre su acusación: lugar del confesionario, nombre, edad y rasgos físicos del confesor, hora y demás circunstancias. Los cuestionarios preveían todo. En Antídoto para solicitantes se criticaba que por dos testimonios inhábiles, como eran considerados los de las mujeres, se pudiera procesar a un confesor y atentar contra su vida y fama. Los procesos con una sola testigo se solían cerrar atendiendo a aquello de que unus testes nullus testes. La mujer

\footnotetext{
${ }^{80}$ Mónica Bolufer, Mujeres e ilustración. La construcción de la feminidad en la España del siglo XVIII, Institució Alfons el Magnànim, Valencia, 1989.

${ }^{81}$ Antonio Domínguez Ortiz, Hechos y figuras del siglo XVIII español, Siglo XXI, Madrid, 1973, p. 230. Carmen Martín Gaite, Usos amorosos del XVIII en España, Siglo XXI, Madrid, 1972, p. 169.

${ }^{82}$ Fray Barbosa decía que era muy verosímil que los trajes profanos y escotados que usan algunas mujeres poco recatadas enseñando los pechos son pecado mortal y se deben excusar conversaciones entre hombres y mujeres pues «Es la muger fuego/ es el hombre estopa/ y el demonio sopla». AUV, Varios, caja 46/7.

${ }_{83}^{3}$ Vicente León Navarro, Luis de Granada..., p. 76. Id., «Probabiliorismo frente a probabilismo. Felipe Bertrán, un antijesuita doctrinal», Disidencias y exilios ..., pp. 627-638.

${ }^{84}$ Jules Michelet, La Bruja. Un estudio de las supersticiones en la Edad Media, Akal, Madrid, 2004.

${ }^{85}$ Gérard Dufour, Clero y sexto..., p. 78. Juan Antonio Posse, Memorias de un cura liberal, CIS, Madrid, 1984, edición a cargo de Richard Herr, p. 46.

86 José Antonio Alejandre, La Inquisición de Sevilla ante el delito de solicitación en confesión, Siglo XXI Editores, Madrid, 1994.
} 
ilustrada era un peligro social, pero tuvo defensores entre clérigos ilustres.

La confesión ponía a prueba al confesor y a la penitente. La proximidad física de hombre y mujer resultaba peligrosa. La mujer se desnudaba espiritualmente ante el hombre-confesor en temas especialmente relacionados con su vida afectiva y sexual. El sexo y el sexto mandamiento se habían convertido en la estrella del confesionario sin más límites que la prudencia del confesor quien con su inmenso poder podía descubrir todos los secretos, fantasías y sueños de la penitente. ${ }^{87} \mathrm{La}$ mujer con todo su misterio atraía al hombre-confesor interesado en la sexualidad femenina, en sus gustos y amores; le importa cómo viste, cómo y con quién disfruta; desea tocarla, besarla, abrazarla, poseerla. La confesión es el momento íntimo y privilegiado del hombre-confesor. El cuerpo femenino, al fin y al cabo materia, se idealiza en detrimento del espíritu.

Para evitar que la pasión despertada por estas confidencias se materializase en actos físicos, se impuso el mueble-confesionario — pieza clave en el proceso inquisitorialpara separar confesores y penitentes, dejando sólo una rejilla, escamoteada cuando la necesidad lo exija. Si la medida era buena, su implantación fue lenta y pronto surgió la picaresca evitando su uso y la casuística que generaba, pues muchos seguían abusando de las sillas, de los bancos o de las mismas gradas del altar, donde la mayor proximidad y el contacto físico permitía ciertas libertades, llanezas y tocamientos incluso en partes íntimas como el capuchino Luis de Mecina con niñas de 12 a 14 años. ${ }^{88}$ Alguno llegó a sentar a la monja penitente sobre sus rodillas, quizás para mayor recogimiento y calor en sus besos y tocamientos. ${ }^{89}$ Algunos obispos estuvieron atentos y a través de Edictos, Cartas y Visitas Pastorales o Constituciones Sinodales, ordenaron que el confesionario estuviese en lugares visibles, dando cuenta de ello a la Curia romana en sus visitas ad limina. ${ }^{90}$ No obstante todas las medidas, la solicitación continuó siendo una lacra clerical que la Iglesia, a pesar de la dureza aparente de los procesos inquisitoriales, toleraba atendiendo a la fragilidad humana de sus ministros. El confesionario era pues un lugar privilegiado para solicitar, para simular confesiones y absoluciones, para concertar citas amorosas y comprar favores. Los más listos sabían distinguir los momentos adecuados para evitar las denuncias y los castigos que podían privarles de confesar, de sus bienes y medios de subsistencia, del exilio o reclusión y también hacer recaer sobre ellos la indignidad y exclusión de su comunidad; otros parecían no darse cuenta del peligro que les acechaba o no les importaba llevados, tal vez, por la pasión o la

${ }^{87}$ Caso de Fermín de Pas con La Regenta, pp. 522 y ss. Clarín, La Regenta, Alianza Ed., Madrid, 1973.

${ }^{88}$ AUV, Varios, caja 54/7.

${ }^{89}$ AHN, Inquisición, legajo 3722/14. Caso de Jerónimo Arnau (Castellón ,1779) y de sor María Gertrudis. ${ }^{90}$ Constituciones Sinodales de Urbina de 1657, Tít. V, Const. VШI. En las de Rocaberti, Tít. III, Const. 2. Fabián y Fuero en AUV, Ms. $860 / 20$ y en su visita ad limina de 1778 alude a ello. En 1709 se imponían los confesionarios de madera con rejilla, evitando sillas y bancos, que a lo largo del XVIIl decae su uso, pero no desaparece como hemos podido comprobar. Stephen Haliczer, Sexualidad en el..., p. 141. 
necesidad física o quizás fiados de su superior autoridad.

No deberíamos reducir la actividad erótico-sexual del clero sólo al confesionario y a las denuncias recogidas por la Inquisición. Éstas, aun siendo muy importantes, constituyen sólo la punta del iceberg de la situación moral que presenta el clero. ${ }^{91}$ Muchas solicitaciones fueron silenciadas. Las actitudes inmorales del clero fuera del confesionario caían bajo la jurisdicción de los tribunales eclesiásticos dependientes de los obispos. Por unos u otros motivos muchos de estos procesos han desaparecido, pero la conciencia popular ha sido consciente de estos desarreglos que ha reflejado a través de refranes, cuentos, canciones, historias, etcétera.

Los 117 expedientes estudiados presentan unos datos aproximados, esperando contar con otros más completos en un futuro, aunque no es lo más importante a nuestro juicio. Sí lo es, por ejemplo, poder entender la red tejida en torno al confesionario, que nos permite ver solicitaciones encubiertas y penitentes solicitadas por varios confesores así como presentar gran parte de la actividad eclesiástica ligada a esta actividad.

\begin{tabular}{|c|c|c|}
\hline $\begin{array}{c}\% \\
\text { Número }\end{array}$ & $\begin{array}{c}\text { Clero secular } \\
14,4 \\
17\end{array}$ & $\begin{array}{c}\text { Clero regular } \\
85,60 \\
100\end{array}$ \\
\hline
\end{tabular}

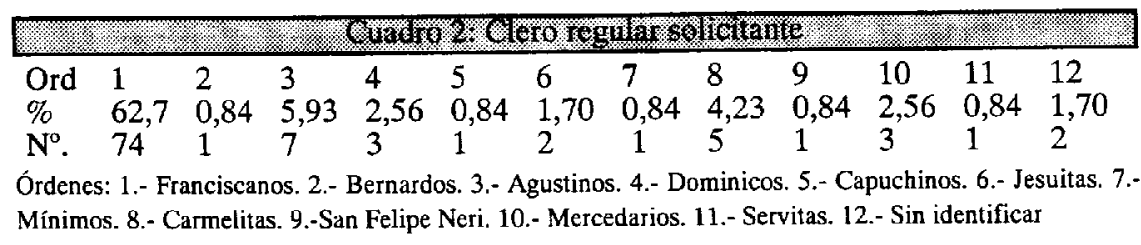

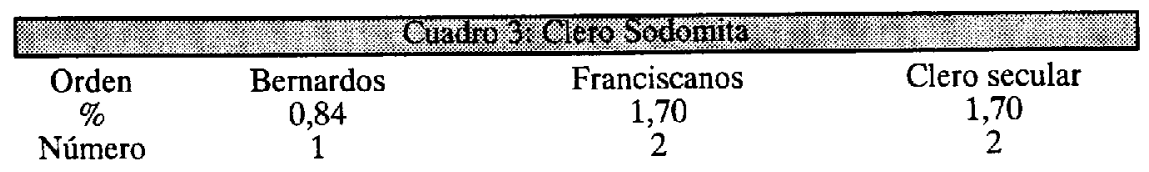

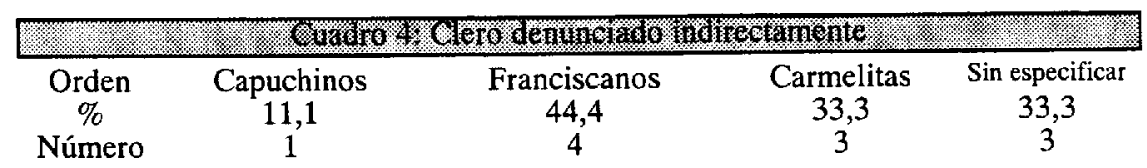

${ }^{91}$ El fiscal en la denuncia contra Agustín Cabadés deja constancia de que quedan otras muchas mujeres con las que también ha tenido iguales atrevimientos, pero no se ha podido tomar razón positiva de sus nombres y apellidos. AHN, Inquisición, legajo, 3722/10. 
Algunos casos denunciados y tramitados por el Santo Oficio son dudosos; se trata de delaciones hechas por penitentes muy escrupulosos que actúan bajo la amenaza eclesiástica. Se observa que el clero regular supera al secular ${ }^{92}$ y entre las Órdenes religiosas las distintas ramas de la familia franciscana disfrutan de un lugar destacado. También es, con mucho, la Orden más numerosa y quizás más liberada y menos ilustrada. Todos los autores destacan este protagonismo aunque con diferencias porcentuales. La movilidad de los regulares en general impedía su control.

La edad media de los solicitantes de 46,60 años resulta engañosa, pues recoge el momento de la denuncia, no el de la solicitación y la diferencia entre una y otra es muy importante en ocasiones. Los denunciantes tampoco saben precisar la edad exacta, la calculan guiados por los rasgos físicos que pueden aportar. Cabría, pues, rebajar esa edad y señalar esos críticos años cuarenta que apunta Haliczer. ${ }^{93}$ El mercedario Cabadés empezó a solicitar a los 30 años y no fue condenado hasta los $53 .{ }^{94}$ El cuadro 5 muestra a quiénes se dirigen las solicitaciones. Por una parte recoge la sodomía masculina, cuya edad media está alrededor de los 17 años, exceptuando dos casos de 52 y 65 años. La edad de las solteras ronda los 22,5 años y llama la atención los casos de pederastia. Sube la edad para las casadas hasta los 29 años y a 40 para las pocas viudas que hemos encontrado. En estos casos, como en el de los solicitantes, la edad convendría rebajarla teniendo en cuenta el momento de la delación y el de la solicitación.

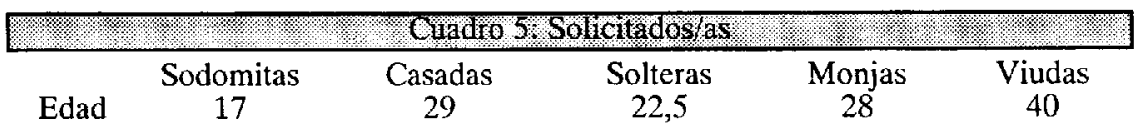

Hemos calculado algo más de 300 personas solicitadas y algunas por varios confesores pero, como señalábamos anteriormente, muchos casos quedan ocultos por miedo a la Inquisición o porque se les convence de que no hay pecado, a pesar de la presión que públicamente se ejercía con Edictos semanales contra los solicitantes. En general, las personas solicitadas pertenceen a las capas más humildes de la sociedad que, por su ignorancia, vinculación a la religión e indefensión, dependen más de la autoridad espiritual del clero y, en este caso, de los confesores que se sirven de su oficio y conocimientos. ${ }^{95}$ Utilizan un lenguaje directo a veces, otras indirecto, sinuoso y lleno de trampas; ofrecen apoyo y limosnas como cebo, esgrimen tener conocimientos médicos para justificar ciertos tocamientos en partes ocultas del cuerpo; favorecen las devocio-

\footnotetext{
92 Juan Antonio Lorente, Historia critica..., pp. 28-29, vol. III.

${ }^{93}$ Stephen Haliczer, Sexualidad en el..., p. 136.

${ }^{94}$ AHN, Inquisición, legajo 3722,10.

95 Jean Pauper, La corrupción...
} 
nes que ellos mismos dirigen así como las penitencias que suelen aplicar con sus propias manos y que las penitentes asumen como una imposición necesaria de la autoridad del confesor. De todo se aprovechan para lograr sus objetivos y quién sabe si creyendo que para mayor gloria de Dios.

\section{Las monjas también se confiesan.}

No faltaron casos de solicitación femenina desde los pies del confesionario. La imagen del clérigo seducido adquiría cierto regusto para algunas mujeres. El confesor tampoco ponía demasiadas objeciones, cayendo fácilmente en las redes femeninas. ${ }^{96}$ Sor Josefa Selma (1788) se jactaba de poder seducir al padre Lorca y dirigirlo a voluntad. ${ }^{97}$ Sor Inés Guitart, de Carcaixent, en mayo de 1709 empezó a solicitar a fray Francisco Talens contándole su vida anterior; cómo era querida, cómo un tío suyo la abrazaba, la besaba y tenía siempre metida la lengua en su boca. Y preguntaba si a él le daría asco hacer lo mismo. El momento parecía propicio y el confesor, que no era de piedra, se sentía removido de arriba abajo y dispuesto a lo que fuera necesario, empezando por algunos recatados besos. Ella añadía un poco más de leña al fuego alabando sus hermosos pechos y él, como santo Tomás, no pudo reprimir ni las palabras de cariño ni la polución. La pasión se desbordó al prometerle el virgo y ya en la reja hicieron manitas y algo más. Tampoco pudo resistir el empuje ardoroso de sor Rafaela en San Mateo (1718) el dominico José Portal de Villanueva al confesarle sus pensamientos impuros con él, quien se le aparecía deseando lo más secreto de su cuerpo. Él, como buen director, la tranquilizaba pues si no había consentido tampoco había pecado y en todo caso convenía estar seguros, mejor que se pasase alguna reliquia o el rosario por sus partes verendas. Cuando en otra ocasión le dijo haber tenido actos impuros consigo misma y «querer descomponerse en su presencia», esto es, que quería mostrarle sus partes secretas, el confesor ardía de pasión ${ }^{98}$ descompuesto también.

La relación confesor-monja siempre ha encerrado una parte de misterio y dado pie a una amplia literatura. Los regulares controlaban esta parcela que, en la mayoría de los casos, pertenecía a la misma Orden y luchaban por mantenerla, por lo que algunos obispos denunciaron la excesiva familiaridad entre frailes y monjas con pretexto de confesión o de dirección espiritual. ${ }^{99}$ Denuncias recogemos que presentan a algunos

\footnotetext{
${ }^{96}$ Hermán relata cómo en varias ocasiones ha sido solicitado y se ha visto mal para salir. Ver en Gregorio Mayans y Siscar, Epistolario XVIII.., p. 308.

${ }^{97}$ AHN, Inquisición, legajo 3722/25.

${ }^{98}$ AUV, Varios, caja $51 / 2$.

99 Fray José Zurita es condenado por solicitación en 1780 en Valencia. Tenía mala fama y eran excesivamente frecuentes sus idas y venidas al convento pasando tardes enteras y muchas horas en el confesionario, confesando a cierta monja. AHN, Inquisición, legajo, 3722/4.
} 
conventos poco menos que burdeles. Las monjas, por su situación conventual, presentaban un grupo especial caracterizado por la represión sexual, la dependencia del confesor, al que solían idealizar, la rutina, la excesiva fantasía y las desavenencias internas. ${ }^{100}$ Con el fin de evitar el abuso de los regulares, Benedicto XIV (1748) publicó Constitutio super designatione confessariorum extraordinariorum pro monialium. Había que romper el círculo vicioso de los conventos de monjas controlados por regulares de su propia Orden, permitiéndoles tener otros confesores extraordinarios y evitar los escándalos. El arzobispo Fabián y Fuero, que algo sabía, en la visita ad limina de 1778 señalaba la prohibición de entrar en los conventos para confesar enfermas sin su permiso por escrito. Quién debía o no confesar a las monjas levantó controversias y ampollas entre las Órdenes, entre éstas y el clero secular por motivos ideológicos y de prestigio ${ }^{101}$ y entre las mismas monjas que soportaron presiones y amenazas. Había gran interés por el confesionario y dirección espiritual de los conventos, no obstante las advertencias de Llorente respecto a la peligrosidad que encerraban estas mujeres ${ }^{102}$ que, cansadas de esperar al divino esposo, apostaban también por el humano.

No andaba desencaminado este buen conocedor de los entresijos inquisitoriales. En muchos procesos encontramos a las monjas víctimas de una situación conventual difícil y anómala. Sor Isabel María Antolí ponía la hostia consagrada en sus partes verendas para más ofender a Cristo y lo repetía con distintas imágenes. ${ }^{103}$ Fray Antonio Sancho quería preparar el asalto a la fortaleza de sor Magdalena y confesándola en Xixona le contaba confidencialmente que estando en una casa por la noche la madre y su hija fueron a su cama a provocarle y tuvo tocamientos deshonestos con ambas. ${ }^{104}$ Lo que quería conseguir quizás fuera lo mismo que el franciscano fray Escrivá (1769) que movía a palabras deshonestas y jugaba a marido y a mujer preguntándole a la penitente si tenía pelos en sus partes y si tenía dos agujeros. Más directo se mostraba fray José Miguel, franciscano de 43 años, con sor Isabel: «Si aqui en el confesionario ubiesse un augero le daría un polvo». Ella timorata respondía cuán deudora era de Dios y él apostillaba: «Señora, déjese de tonterías que todos sus pecados me los juego por bajo la pierna». Maja debía ser sor Josefa Teresa de Santa Rita para hacer decir al francisca-

${ }^{100}$ Blanco White, Cartas de España, Alianza, Madrid, 1977, pp. 150, 182, 197. Alonso Andrade escribía en 1644 Libro de guía de la virtud y de la imitación de Nuestra Señora y señalaba el peligro de las monjas y su vulnerabilidad. El pueblo satiriza esta relación frailes-monjas: «Un fraile y una monja/ dormían juntos/ porque tenían miedo/ de los difuntos». Ver Lettres d'amour d'une religieuse portugaise. AHN, Inquisición, legajo 4486/6. Libro prohibido. Retrata el interior de los conventos.

${ }_{101}^{01}$ José Zurita, que tenía gran apego a las monjas, las aleccionaba ante los confesores extraordinarios: aCuidado no le digas a ese capellanet que ve a veuret alguna cosa que siga en descrèdit del pare definidor». Se refería a él mismo. AHN, Inquisición, legajo, 3722/4.

${ }^{102}$ Juan Antonio Llorente, Historia crítica..., p. 30, vol. III.

${ }_{103}^{103}$ AUV, Caja 56. El proceso dura desde 1752 a 1764.

${ }^{104} \mathrm{AHN}$, Inquisición, legajo $3722 / 5$. La copla viene bien: «Entre la hija y la madre/ tienen ar cura del pueblo/ lo mesmeto qque un alambre». 
no Juan: «Muger, tú y yo somos capaces de encender un castillo». Castillo almenado le parecían al agustino Joaquín Cascant de Alcoy (1803) las paredes del convento que le impedían conseguir sus fines, y limitado por todas partes, gozaba explicando a sor María Lucinda los movimientos y deseos impuros que pasarían en su interior. Ignoramos si tenían lugar en los de ella, pero seguro que sí en los de é $l,{ }^{105}$ como en los de Vicente Flores, franciscano de 50 años, alto y delgado (1815) que algo triste aseguraba a la monja: «Ojalá pudiera yo cometer acciones torpes contigo» y como no lo conseguía le pedía que discretamente corriera la cortina de la rejilla y se descubriese los pechos y le instaba a que fuese a la reja del convento. ${ }^{106} \mathrm{~A}$ pesar de ciertas facilidades, los confesores se encontraban con muchos inconvenientes para conseguir sus ardorosos deseos que terminaban, cuando no había otro remedio, en encendidas declaraciones de amor.

La familiaridad de fray Pedro Hernadorena, franciscano, y de sor Antonia Fita les permitía confidencias íntimas entre inocentes y picaronas. Le contaba él que sudaba tanto por los sobacos que el vello se le pegaba y cuando alargaba el brazo le tiraba. Ella comprensiva le aconsejaba cortarse el vello. Pero él iba más lejos y puestos a intimar le comentaba las molestias que tenía al polucionar durmiendo o medio dormido porque se le pegaban los paños y el vello en los muslos y le dolía. Además le sudaban las ingles. Ella, como mujer, también tenía sus problemas pues el modo de vestir le incomodaba los pechos, ya que al no sujetarlos su peso la fatigaba y le causaba dolor. Y bien que conocía cuando le venía la regla porque se le hinchaban los pechos. ${ }^{107}$

Juan de la Cruz preguntaba a sor María Agustina, 33 años, en acto de confesión y antes de darle la absolución, a qué edad se había perdido. Ella respondía que a los 13 o 14 años. Fray Juan, obsesionado por los tamaños, se sorprendió: «Pues, demonio, ¿cómo te lo pudieron meter teniendo el agujero tan pequeño y teniéndolo los hombres tan gordo? Te debieron hacer mucho mal. Escúchame....»; y continuó el interrogatorio adentrándose en las profundidades sexuales, que no morales ni teológicas. Boquiabierta debió quedar sor Tomasa de 17 años al ser preguntada si en sus actos carnales se había sentido mojada y si en éstos se ponía encima o debajo y si al confesar con él sentía movimientos carnales. No quedó menos atónita y turbada sor Tadea, 23 años, al oír si se había tocado la figa y cuántos hombres se lo habían hecho y cuántas veces y si había parido. Más que un convento aquello, a tenor de las preguntas del confesor, debía ser un lupanar. Más espiritual parecía Juan Salvador (1714) al proponer a sor Jerónima de 22 años que fuera su madre espiritual para comunicarle sus tentaciones. Pero la espiritualidad se transformaba en lujuria; el muy pillo le contaba que había soñado «que

${ }^{105}$ AUV, Varios, caja 69/6.

${ }_{100}$ AUV, Varios, caja $70 / 15$.

${ }^{107}$ AUV, Varios, caja 61/10. 
llegava a una mujer y tenía poluciones y sus partes alteradas». ${ }^{108}$

El caso del dominico Francisco Carrá, confesor de varios conventos de Valencia, proporciona materia para un buen estudio. Este padre empezó confesando a los 35 años (fue denunciado cuando tenía 42 en 1770). El fiscal señalaba que, aunque estos delitos no fueran los más graves, se podían catalogar como los más enormes, que eran infinitos y repetidos y de los más deshonestos y obscenos que la infernal astucia podía inventar dentro de una religiosa clausura y consumada en recinto sagrado y dentro de los límites del sacramento de la penitencia, al que había herido de lleno. El fraile se delató voluntariamente por precaución pues sabía que iba a ser denunciado. Miedo pero no arrepentimiento. Entre las diversas declaraciones de las monjas nos centraremos sólo en el testimonio de sor Gracia María y en la astucia con que actuó el confesor.

Cuando sor Gracia se acercó un día al confesionario, el padre le ordenó besar primero el suelo; más tarde tumbarse en cruz mientras le culpaba de los sufrimientos de Cristo. La monja asumía su falta pidiendo satisfacer al Señor. Empezó poniéndole un cilicio en la cabeza y un lazo en el cuello para tirar de él a través de la rejilla pues así maltrataban a Cristo. Con estos juegos se entretuvieron confesor y penitente un año. Más tarde le ató una cuerda de cáñamo al cuello y le hacía andar por el confesionario y cuando estiraba ella caía al suelo; esto era bueno porque así trataban a Cristo. Luego debía azotarse, siempre pensando en el Scñor, por encima de las ropas y más tarde con las ropas levantadas. Carrá vivía la pasión de Cristo, pero sobre todo su propia pasión, y al igual que Cristo fue despojado y expuesto a la vergüenza pública ella también debía hacerlo, pero ¿se lo merecía? En su opinión no, atacando la fibra sensible de la buena monja sumida en su simpleza. Era suficiente para que, herida en su orgullo, suplicase tomar con más entusiasmo la iniciativa de agradar al Señor. Él debía ceder permitiendo que descubriese primero sus pechos y, poco a poco, quedase desnuda como Cristo. Días después, inspirada por san Luis Beltrán, devoción que el confesor le había inculcado, aparecía cubierta con un sudario que Carrá toleró se quitase quedándose en cueros. De esta guisa le ordenó ponerse ya de frente, ya de espaldas, ya de pie, ya tumbada con las piernas hasta la reja del confesionario hasta tocarle sus partes. Después de semejante acto circense había merecido la absolución sacramental.

En otras ocasiones a través de la rejilla le lamía los pechos, los pellizcaba o con una aguja de cabeza crecida los pinchaba. Ella colaboraba aportando agujas de hacer media y alpargatas; así pagaba mejor por sus pecados y sentada frente a la reja se levantaba la ropa y él con tres agujas atadas le pinchaba sus parte verendas y le pedía que apartase el vello y abriese bien dicha parte para verla, lo que ella ejecutaba con toda humildad.

${ }^{108}$ Id., 50/7. 
Apurando un punto su astucia y deseo de saber, fray Carrá le mandó restregase los pechos unos sobre otro y mordérselos; luego que le enseñase sus partes, se metiese el dedo en ellas y tirase de los pelos. Le hacía levantar la ropa por detrás puesta en venía profunda de modo que tocaba la reja y él la mortificaba, como era menester, con la punta del dedo o con las agujas. Ésta era la clase práctica. La teórica vendría después. Y llegó el día en que le preguntó cómo se llamaban esas partes. Ella, algo corrida, no se atrevía, pero al fin respondía: «Lo que tinc entre les cames y les parts de darrere». La respuesta era demasiado general y el fraile exigía precisión. Ella que no tenía clara esta línea pedagógica susurraba: «El badall que tinc entre le cames»; pero no era suficiente, el padre pedía más, porque a las cosas había que llamarlas por su nombre. Sor Gracia algo turbada precisó: «El botó que tinc entre les cames». Superada la primera parte se pasaba a la segunda, había que completar el temario. ¿Cómo se llamaba lo de detrás? Para ella se trataba de: «Les assentaeres», pero como el confesor exigía más tuvo que concretar: «Les anques» y un poco más «el cul» y finalmente «el ull del cul?. Este sistema se repitió varias veces a lo largo de 5 o 6 meses. Ya en el año 1769 , y tras muchas confidencias, ella quiso dar un paso más en el camino de la perfección diciéndole al padre cuánto mejor podría pagar por sus pecados si no estuviese la reja. Y en ese caso qué haría él, preguntaba la buena monja. El astuto confesor le pasó la pelota a ella, ¿qué quería sor Gracia entonces? Ella sólo deseaba que le mortificase todo su cuerpo. El curioso Carrá necesitaba saber hasta dónde podía llegar. Ella, que ya había aprendido la precisión de los términos, respondía: «En los pechos y en el botó que tenía entre les cames». El confesor parecía satisfecho de su método y seguro que podría decirle también cómo hacerlo y si era necesario quitarse toda la ropa. Ella prefería que ambos quedasen desnudos; él sentado encima le mortificaría los pechos con las manos y con la boca y también el «botó» metiendo en él el dedo. Carrá quería saber con qué más mortificaría el botó. No había problema, tumbándose encima la mortificaría por detrás. «¿Cómo?» Insistía él. «Con las manos», respondía ella. Y « ¿con qué más?» inquiría él que veía cerca la hora del triunfo. Ella aclaraba: «ficant el seu botó en el forat de darrere». Estas conversaciones tuvieron lugar en diferentes ocasiones escenificadas por la buena monja mortificando su botó como si él estuviera encima. Según él aquello no podía ser mientras la hermana subida al carro de la perfección quería que «se deje pagar al menos mortificando su botó metiéndole los dedos con movimiento». Mortificación que le ponía fuera de sí exclamando: «pare, el cos, sent, sent». Él preguntaba solícito: «¿Dónde?». Ella respondía: «En el botó»; y en otras ocasiones: $\ll$ Pare, ya me encenc», y él sonsacaba si advertía humedades en aquella parte y ella lo confirmaba.

Pero sor Gracia, que aspiraba a un nivel superior, necesitaba que el padre la mortificase más enseñándole «el seu botó». Aunque al principio se resistía, acabó cediendo a la buena causa con un: «Bien, yo lo haré». Puesta la monja ante la reja con la ropa 
levantada el confesor mortificaba el botó con el mango de un abanico ayudándose ella con los dedos y diciendo: «Anem, pare, manifeste vosté el seu botó», lo que oído por Carrá prometió seguir sus instrucciones. Ni corta ni perezosa pidió que se levantase de la silla, se alzase la túnica y que se bajase los calzones y calzoncillos y que se pusiese de lado porque le venía mejor la luz de esa parte. El ejecutó con sumisión todo y colocado al lado de la reja pudo ella tocarle el miembro viril y mientras sor Gracia se mortificaba Carrá se interesaba por la anatomía femenina: «Cuántos agujeros tenía?». Ella aprobaba respondiendo que dos. Seguía el examen, ¿cuál era mayor? Ella apuntaba al de arriba: «Por donde sale la espuma». Él ya estaba encendido al responderle: «Pues si pudiese lo haría más grande». En ascuas quedó ella. Él concretaba que: «Metiendo el botó». De nuevo la monja se interesaba por saber si se mortificaba mejor con uno o dos dedos. Qué preguntas, pues con todos los que pueda, venía a decir el fraile que no hacía ascos a tales dedos ni a explicar los pormenores de su miembro viril. ${ }^{109}$

\section{Laicos en el confesionario.}

Los confesores actuaban de forma distinta según las situaciones buscando poder materializar los deseos a los que les inclinaba su naturaleza. Satisfacer el deseo sexual se transformaba en una meta que cada cual llevaba a cabo como podía, aprovechando la oportunidad que les brindaba el confesionario. Rosa Reig, 31 años, contaba que fray José Tudela, en San Felipe (Xàtiva, 1794), al confesarla, se ponía las manos bajo el hábito y al entrar en materia venérea le mandaba repetir los hechos hasta doce veces y observaba movimientos deshonestos y gran complacencia en el fraile y no la absolvía hasta haber satisfecho sus necesidades sexuales. ${ }^{110}$ De forma más o menos directa el confesor solicitante creaba el ambiente propicio para sus fines. Andrés Bernabeu (1707) echó mano a las partes verendas de la penitente varias veces. A otra, a la que empezó confesando con diez años, le pedía le tocara sus partes. ${ }^{11}$

El cura de Montán (1726) confesando a María Martín, 24 años, le decía: «Señora María, me ha de dar el coño» y a María Oliver, 34 años, le preguntaba si cuando lo hacía con su marido pensaba en él; a Francisca Gil de 30 años le prometía todo si le daba el coño porque quería hacerle un hijo. Buen concepto de sí mismo debía tener también Vicente Chapuy (franciscano, 1766), ${ }^{112}$ cuando preguntaba a Francisca María Ballester de 24 años: «Si estando allí a sus pies tenía alteraciones y algunas humedades en sus partes»; le hizo la pregunta varias veces y la llevó a la sacristía para preguntárselo

\footnotetext{
${ }^{109}$ AUV, Varios, caja 61/1.

${ }^{110}$ Id., 66/6.

111 Id., $48 / 4$.

112 Id., $60 / 2$.
} 
de nuevo con la intención de comprobarlo él mismo, como un nuevo santo Tomás.

Francisco Torá resultó ser un pícaro. En Morella (1779) confesando a Francisca Adel, 24 años, al llegar al sexto mandamiento quiso averiguar sus conocimientos sobre anatomía. Le preguntó por el nombre del miembro viril. No respondió y él condescendiente apuntaba: «Se llama maniqueta», A partir de aquí desbrozaba el camino con preguntas más delicadas, tales como si habían derramado en sus manos, en el delantal o en la camisa, si era claro o espeso, si le metían la lengua en la boca y si cuando le venía perdía la luz de los ojos. La penitente le dejó plantado. Pero él continuó con María Muñoz, 22 años, quien con pesar contó cierta deshonestidad a la que el confesor no dio importancia: «Eso no quiere decir nada; de esos pecados cuantos más se cometan mejor; los mismos puedo cometer yo". También en este caso la penitente amenazó con irse, pues no eran formas de confesar. Pero la pedagogía corporal siguió con otros. Bernardo Hervás, beneficiado de Carlet (1782), inquiría a Teresa, 21 años, dónde tenía sus partes. Ella permaneció callada y él se respondia: « ¿Sabes dónde las tienes? Bajo la barriga». Y siguió: «¿ Cómo tienes tus partes?». Al continuar callada, él la documentó: "Sabes cómo las tienes?, llenas alrededor de pelos». Antonio Sancho estaba preocupado por las medidas y preguntaba a Rita María, 22 años «si tenia prou» hablando de sus partes verendas; «si tenia els pits grossos o prou grossos»; ella respondia: «Prou per a mi». Obsesionados por la anatomía femenina estaban Valero y Manuel Benlloch. ${ }^{113}$ A Juan de la Cruz le preocupaba cómo lo tendría el marido de Margarita, recién casada, quien le daba las explicaciones pertinentes, sin más. ${ }^{114}$ Similar interés mostró tener Hervás al demandar a María Montesino, 21años, cuántas veces se lo hacía su marido, cómo, cuánto tiempo duraba y cómo lo tenía. ${ }^{115}$ La línea pedagógica la seguía el franciscano Agustín Soriano, que amén de interesarse sobre todo lo concerniente a las cuestiones sexuales femeninas y masculinas, posturas, etcétera, aclaraba, como entendido, que había dos tipos de derramamiento, uno pecaminoso y otro no, según sirviera para hacer niños o no. Claro que este buen fraile, según él, sólo lo preguntaba para saber cuántos pecados habian cometido sus penitentes. Otros presumían de consejeros. Fray Jaime Sánchez (1801), sugeria a Esperanza Pichó, 38 años, que cuando tuviese el menstruo cuidase y lavase sus partes con sus propios orines y así no se le pegarían los pelos. ${ }^{116}$ Recetas y recomendaciones que en ocasiones ponían al descubierto ignorancias, tabúes y atrevimientos. El padre recomendaba tranquilidad a la monja preocupada por si ciertos dolores pudieran ser embarazo consecuencia de algunos actos deshonestos habidos en el siglo. El confesor le explicó en paladín castellano lo que debia haber sucedido para

${ }^{113}$ AUV, Varios, caja $68 / 5$.

114 AUV, Varios, caja 59/2. Año 1765.

115 AHN, Inquisición, legajo 3722/42 Añol782.

${ }^{116}$ AUV, Varios, caja 69/9. 
que se hubiera quedado preñada. Algo peligroso resultó Jaime Caselles, franciscano de Pego, al solicitar a su propia sobrina, asegurándole que no pecaría, que todo el pecado recaería sobre él.

\section{También fuera del confesionario.}

Algunos confesores, que se contenian en el confesionario por recato o por prudencia, terminada la confesión buscaban a sus penitentes para lograr lo que no se habían atrevido a solicitar en el acto de confesión y aprovechaban los lugares más apartados y oscuros para intentar satisfacer sus encendidos deseos. Francisco Urrios (1713), le declaraba a Margarita Adam su amor y mientras se mostraba deseoso de ir a su casa, le alargaba las manos a los pechos, alabando su hermosura y anhelando tener parte con ella. Debió ser convincente porque al cabo de un cuarto de hora ella le permitía el acceso a sus parte más íntimas, aunque con cierta resistencia por no ser oportuno el momento o tal vez el lugar. Pedro Gavaldá (1745), después de confesar a María Magdalena, la llevó a una estancia apartada. Ante su desdén la amenazó con que se acordaría de él. La besó y la persuadió a tener comercio carnal, como sucedió. Cuando volvió a confesarse le pregunto si le había gustado y si se deleitaba con el recuerdo. Buena doctrina daba el mercedario confesor de Esperanza Pichó, 38 años, en 1801 dentro del confesionario, pero acto seguido le salía al encuentro para ofrecerle cuanto tenía con las palabras más cariñosas del mundo para conseguirla. ${ }^{117}$

Hubo quienes aprovechaban el momento de la confesión para averiguar el domicilio de sus penitentes con la intención de visitarlas. Así lo hizo Buenaventura Sevilla con Antonia Fuster, y se trataron cariñosamente. Entre regalos, dulces y rosarios, él le tocaba los pechos. La invitó al convento donde simularon la confesión. Ella correspondió y él se animó aumentando los tocamientos en carne y los ósculos. Diego Joaquín fue más lejos. Tras la confesión se dio una vuelta por el domicilio de Juana Navarro (1695) donde tuvieron acto carnal. José Rico (1714) se interesó por la casa de Ana María para visitarla y manifestarle su amor, instándole con abrazos a gozar y seminando sobre sus carnes a pesar de su resistencia. ${ }^{118}$ Similar inclinación mostró el franciscano Pascual Ferrando (1808) cuando le decía a su penitente: «Que sea buena, que en este mundo no somos nada» y convenía aprovechar las situaciones, ${ }^{119}$ como hacía en Carcaixent (1810) el también franciscano Ignacio Bernabé, 40 años, que solicitaba a Bernarda Cogollos en el cuarto donde solía dormir la siesta tras confesarla y haber comido en su casa. ${ }^{120}$

${ }^{117}$ Id., $54 / 4$.
${ }_{118} \mathrm{Id}, 50 / 6$.
$119 \mathrm{Id}, 70 / 6$.
$120 \mathrm{Id}, 70 / 9$. 
El deseo sexual no respetaba tampoco a las enfermas reales o fingidas. El franciscano Bertomeu (1705), confesada Gerónima, pasó del beso a los pechos en carne con fines poco honestos. Ocho días después fue a más, pasando a piernas, muslos, vientre y costados. ${ }^{121}$ El fraile de la Congregación, José Ferrando (1765), fue a confesar a sor María Carmelo de 40 años al convento de la Encarnación y la solicitó tocándole los pechos, si bien ella se resistió él se hizo obedecer. Ocho días después ya en el confesionario Ferrando quería llegar a sus partes. Poca resistencia le ofreció la monja, pues pasando a la reja mientras él se aprovechaba ella le susurraba «si sería voluntad de Dios hacer lo que hacían». Fray José aseguraba que cuanto más le obedeciese mayor sería el gusto de Dios. ${ }^{122}$ Si la confesión requería sumo secreto, el cuarto de la enferma era idóneo para estar a solas. Esto lo pensó el agustino Padilla (1784) al ser llamado por Tomasa sin permiso del médico. Momento que aprovechó para tocarla a placer tras negarse a confesarla y cerrar la puerta de la habitación. Placeres experimentaban también en el Hospital General los confesores M. Sanchis y Sebastián Ponciano. ${ }^{123}$

\section{¿Y la penitencia?}

Íntimamente ligada a la confesión andaba la penitencia que el confesor aplicaba según su vara de medir y ajustada a los pecados confesados. Debido al secreto no solían describirse excepto en los casos denunciados al Santo Oficio que aparecen con todo lujo de detalles al ir unidas a la solicitación. Se trataba, en buena medida, de la mortificación en diversos grados (disciplinas, tenacillas, cadenillas, disciplinas de sangre, cilicios) -sadismo o sado-masoquismo místicos según los casos-. Algunos confesores se inclinaban por esta penitencia, pidiendo incluso su cumplimiento antes de la absolución. Otros, daban tiempo para su ejecución pero con el control que les permitía tanto aplicarla con sus propias manos como examinar sus efectos (sangre, heridas, llagas, etcétera) con la vista o con el tacto, por encima o por debajo de la ropa. ¿Se trataba de una penitencia erótica o de un erotismo pseudomístico? Tal vez no fuera más que pretexto para ciertas satisfacciones sexuales, aunque los denunciados negasen haber experimentado placer en tales prácticas que escondían una idea algo sentimental, aberrante y deformada de los sufrimientos de Cristo, de la naturaleza humana corrompida y del hombre todo pecador sumido en la nada. Encontramos así las tendencias teológicoespirituales más polémicas dentro de la Iglesia entre los defensores de la libertad del ser humano y los detractores que niegan su capacidad para salvarse por sí mismo y abogan por el abandono y la inactividad a ejemplo de Molinos. El cristianismo se convierte en

12: Id., $48 / 5$.

$122 \mathrm{AHN}$, Inquisición, legajo 3722/26.

123 AUV, Varios, caja 63/7. 
la religión de la negación, del dolor, del sufrimiento, de la tristeza, del pecado, del desprecio al propio cuerpo que paga los pecados cometidos supuestamente por el espíritu. Triste herencia que se arrastra desde los primeros tiempos. El señor Sade no inventó nada.

El franciscano Gerónimo Bolado (1755) impuso a Josefa Selma casada, 33 años, unas disciplinas. Pronta a satisfacer la penitencia se retiró a la capilla de santa Bárbara. Bolado, al no oír lamentos desgarradores, se presentó allí para dárselos por propia mano. Y lo mismo ocurrió en su casa. Un buen día que no estaba el marido, Bolado pasó a casa de Josefa y le pidió que le mostrase las disciplinas con que se mortificaba. Le parecieron flojas y le ordenó darse algunos golpes en la habitación. Tampoco le satisfizo la acción y entrando, tras pedirle obediencia, le levantó las sayas y le dio unos buenos golpes con cierta resistencia de ella. ${ }^{124}$ Fray Mateo Bernat debió de hacer un esfuerzo cuando Francisca Chorba, doncella de 22 años, le pidió en confesión «que necesitaba llevar cilicio» y no tenía. Bernat le propuso comprar el material y hacérselo él mismo. Llegado el momento, en la sacristía, el perito fraile se lo colocó bajo las sayas sin tocarle las partes íntimas ni aun la carne. Luego buscaron un escenario más bucólico en el monte donde debajo de un árbol se lo ponía, se lo quitaba o se lo ajustaba. ${ }^{125}$

El agustino José Padilla ordenó azotarse a Mariana Guillén (1785). Desconfiado se personó en su casa y llevándola a una habitación le recriminaba: «Yo te llamo para que te mortifiques, échate boca abajo y sobre la cama y con estas disciplinas te pegaré en el culo». Ella se resistió: «Padre, eso no lo consentiré yo». Él hizo respetar su autoridad: "¿Cómo que no? Yo soy tu padre, en esto no puede haber escrúpulo, tengo poder para hacerlo». Y lo hizo mandándole que al día siguiente se confesase con él. En acto de confesión le aseguró: «Ayer te azoté con mis disciplinas; te ví las ancas y te las toqué, pero yo no sentí conmovida mi naturaleza y no pequé, lo quiero repetir para vuestra mortificación». Ejercicio que practicaba Valero con sus penitentes con deleite y profundidad. Entre sus confesadas tenía un grupo que se disciplinaban mutuamente, desnudas o semidesnudas; algunas exigían más mortificación y se les colocaba aliagas y ortigas en la cama. A Manuela Benlloch le aconsejaba diferentes disciplinas, cuyos efectos controlaba él tocando los lugares afectados. ${ }^{126}$

El caso más extraordinario fue el del carmelita fray Tomás de San Vicente, 50 años, en la localidad de Artana donde creó un grupo de penitentes de las que obtuvo votos de castidad, pobreza y de absoluta obediencia. A Antonia Mechó, sobrina del cura del pueblo, le aconsejaba disciplinarse en sus partes secretas. Por la rejilla le daba cera para

${ }^{124}$ AHN, Inquisición, legajo 3722/70. Helena Sánchez, «Flagelantes licenciosos y beatas consentidoras. Prácticas penitenciales en el Antiguo Régimen», Historia I6, año IV, n⿳亠丷厂 41 (1979).

${ }^{125}$ AUV, Varios, caja $59 / 1$.

126 Id., 68/5. 
que derretida dejase caer gotas en sus pechos, muslos y los lados de sus partes, preguntándole luego si alguna había caído dentro y pidiendo que le enseñase el daño y que no tuviese reparos pues "soy tu padre». Le recomendaba que al sentarse a trabajar se metiese la mano por debajo del delantal y tirase de los pelos de sus partes. María Villalba incluso disciplinaba al fraile ante las otras penitentes, le echaba cera en los muslos y él a ella, le restregaba con ortigas y le curó el mal de la disciplina con orines propios. Ella le escupía en la boca, le abofeteaba y dos o tres veces se meó y aún excrementó en su boca. Él le lamió con su lengua por entre los muslos por detrás dos veces, según él «para que veas que no tengo ningún escrúpulo de ti». Se juntaban y se disciplinaban entre sí algunas veces en cucros. A María Carmela y a Manuela les pedía que se azotasen juntas en las nalgas con ortigas y se las aplicasen en sus partes secretas. Todo tenía su explicación. Las gotas de cera ardiendo en los pechos, en las partes y en los muslos se hacía en honor a las cinco llagas de Cristo y a los siete dolores de la Virgen. La recomendación de tirarse de los pelos de sus partes era en recuerdo de los sufrimientos de Cristo arrastrado por los cabellos. ${ }^{127}$

\section{La sodomía.}

Este pecado nefando, vil y abominable no fue ajeno tampoco al confesionario. La Iglesia, siguiendo la doctrina tomista, supo inculcar su peligrosidad en la sociedad a pesar de contar con sodomitas entre sus ministros. Tal vez la vida conventual ${ }^{128}$ se convirtió en lugar propicio actuando como centro de atracción para quienes huían precisamente del mundo donde se castigaba con severidad ese pecado contra natura. ${ }^{129}$ La progresiva relajación de los claustros favoreció estos comportamientos que los superiores, en muchos casos, toleraban para esconder sus propios vicios. Su persecución fue cruel en determinados momentos porque, señala Tomás y Valiente, truncaba el orden divino de la creación en el que el acto sexual se vinculaba sólo a la procreación, evitando cualquier placer, incompatible con la moral católica, moral de pecado. Por tanto, todo acto sexual dirigido al placer sin procreación constituía un grave pecado que atentaba contra Dios y el orden natural del que Él era legislador. ${ }^{130}$ De ahí la insistencia de los confesores en saber cómo se realizaba el acto sexual, su finalidad, la seminación intra o extra vas, si fue con la intención de quedar encinta o no, si hubo placer o si se procedió retro more pecundum aunque en el vaso natural. El tiempo dedicado al sexto

\footnotetext{
${ }_{127}^{127}$ Id, 64/1. AHN, Inquisición, legajo 3722/3.

${ }^{12 x}$ Son numerosos los casos. El monasterio de bernardos de la Valldigna. El prior del convento de Carmelitas en Xàtiva, que cuenta Rafael Carrasco, Inquisición y represión en Valencia. Historia de los sodomitas, 1565-1785. Laertes, Barcelona, 1986, p. 129.

${ }^{129}$ Rafael Carrasco, Inquisición.

${ }^{130}$ Francisco Tomás y Valiente, «El crimen y pecado contra natura», Sexo barroco ..., pp, 33-55.
} 
mandamiento en la confesión y en los manuales se aprecia bien en el Fuero de la conciencia de fray Valentín de la Madre de Dios, cuya lectura no tiene desperdicio. Nada es baladí en esta casuística barroca y trasnochada. Cuando el cura Miguel Martínez, beneficiado del Patriarca, se acusa de haber tenido relaciones con bastantes mujeres durante unos 16 años, no lo hace por haber tenido comercio carnal sino por haberlas atacado preposterum por miedo al contagio del mal gálico y por ello se acusaba de sodomía. ${ }^{131}$

El franciscano Gabriel Vives de 48 años jugaba a dos barajas. En Denia a Josefa de Rafel, 19 años, la acosaba: «Si yo te cogiera en lugar estrecho...». Pero el éxito lo tenía con los mozos. En 1740 Juan Carbonell declaraba que después de la confesión el fraile le pidió subir a su celda donde empezó a abrazarle y a besarle. Llanezas que aumentaron con el tiempo, primero metiendo sus partes en la boca de Juan y luego introduciendo el miembro viril «por el oculo prepostero, aunque no recuerda si derramó o no». Que estaban a gusto lo confirman las 6 o 7 veces que el mozo actuó de sujeto y las 30 que lo hizo de paciente. Vives en noviembre de 1740 relataba su activa vida sexual dejando huellas de su paso. En el convento de Callosa se acostó con un joven de 19 años y «llevado del demonio tuvieron actos sodomíticos, actuando él de paciente pero sin seminación interior...»; en Onda predicando la Cuaresma se entendía con un joven estudiante al que a cambio de los recados le repasaba la Gramática y con tanto repaso encendieron el fuego de la pasión con tocamientos que le llevó a la introducción del miembro viril; y lo mismo pasó cn Guadalest, en Benisa y en Bocairente.

José Gracián, franciscano de Sueca (1786), era acusado por Ventura García, Vicente Carrasquet, Pascual Viel, Mariano Ferrando y Josep Iborra de 18, 17, 18, 19 y 15 años respectivamente por solicitante en confesión, momento aprovechado para tocamientos y besos. A Vives le pidió que le tocase sus partes. Necesitando desahogarse salía por los campos a pasear con el fin de pervertir a los mozos induciéndolos a tocamientos torpes. Viel se confesaba en la celda a puerta cerrada; a otro le pedía le tocase el miembro mientras él procuraba tocar el del muchacho y luego le absolvía sacramentalmente. No era privativo de los conventos, por supuesto. El cura de Campo de Salinas en 1776 durmió en casa de Juan Rico de Elda y en la siesta y por la noche, como dormian juntos, le besaba y le cogía por sus partes con intención. También Jonás Zaragoza, 52 años, había tenido tocamientos con efusión de semen mientras el cura le decía que no era pecado. A José Buendía, de 65 años, le tocaba sus partes, le besaba y le mordía la lengua. Sorprende el caso de Manuel Pérez casado con Isabel Lorenzo. Una noche que el cura se quedó a dormir se acostó con Manuel, posiblemente con el consentimiento de la mujer que, extrañada al día siguiente por encontrar restos de la batalla

${ }^{131}$ AUV, Varios, caja 69/7. 
sexual y de los ruidos nocturnos, debió preguntarle la causa; él sonrojado la miró con furor culpándola de lo sucedido. El cura, que tenía mala fama, andaba por todas partes tocando cuanto se ponía a su alcance sin ningún pudor. ¿No lo sabían Manuel e Isabel?

Hemos intentado presentar en estas páginas un tema polémico y delicado cual es el de la confesión y los abusos cometidos en su ejercicio, cuyo origen podemos encontrar, primero, en la obligación impuesta por la Iglesia; segundo, en los temas tratados y tercero, en la condición célibe del confesor. Es cierto que la Iglesia ha velado por la pureza de este sacramento, pero también es verdad que el abuso del poder eclesiástico to ha degradado hasta hacerlo odioso, inútil y contraproducente, aunque ha sido un elemento fundamental de control de los fieles, de las familias y de las sociedades. El que los delitos de solicitación cayeran bajo la jurisdicción del Santo Oficio nos ha permitido conocer documentalmente parte de la vida sexual del clero, mantenido célibe por la jerarquía para controlarlo mejor. Sorprende la minuciosidad y realismo con que la Inquisición trató este asunto. El rico sistema procesal que nos proporciona tantos elementos de análisis y de reflexión, no debe hacernos olvidar el perverso y degradante sistema inquisitorial, raíz de contemporáneos y posteriores males hispanos. 